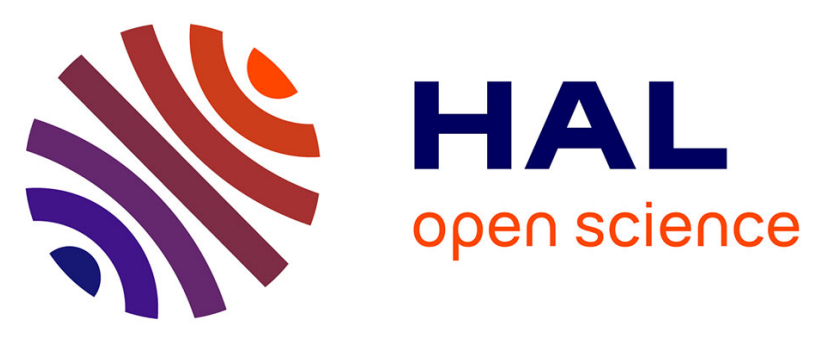

\title{
14 kyr of atmospheric mineral dust deposition in north-eastern China: A record of palaeoclimatic and palaeoenvironmental changes in the Chinese dust source regions
}

Steve Pratte, Kunshan Bao, Atindra Sapkota, Wenfang Zhang, Ji Shen, Gaël

Le Roux, François de Vleeschouwer

\section{To cite this version:}

Steve Pratte, Kunshan Bao, Atindra Sapkota, Wenfang Zhang, Ji Shen, et al.. 14 kyr of atmospheric mineral dust deposition in north-eastern China: A record of palaeoclimatic and palaeoenvironmental changes in the Chinese dust source regions. The Holocene, 2020, 30 (4), pp.492-506. 10.1177/0959683619892661 . hal-02990229

\section{HAL Id: hal-02990229 \\ https://hal.science/hal-02990229}

Submitted on 16 Nov 2020

HAL is a multi-disciplinary open access archive for the deposit and dissemination of scientific research documents, whether they are published or not. The documents may come from teaching and research institutions in France or abroad, or from public or private research centers.
L'archive ouverte pluridisciplinaire HAL, est destinée au dépôt et à la diffusion de documents scientifiques de niveau recherche, publiés ou non, émanant des établissements d'enseignement et de recherche français ou étrangers, des laboratoires publics ou privés. 


\title{
14 kyr of atmospheric mineral dust deposition in north- eastern China: A record of palaeoclimatic and palaeoenvironmental changes in the Chinese dust source regions
}

\author{
Steve Pratte,1 Kunshan Bao,1,2 Atindra Sapkota,3 Wenfang Zhang,1 Ji Shen,1 Gaël Le \\ Roux4 and François De Vleeschouwer4,5
}

1State Key Laboratory of Lake Science and Environment, Nanjing Institute of Geography and Limnology, Chinese Academy of Sciences, China 2School of Geography, South China Normal University, China

${ }_{3}$ State Key Laboratory of Environmental Geochemistry, Institute of Geochemistry, Chinese Academy of Sciences, China

4Laboratoire écologie fonctionnelle et environnement (EcoLab), Université de Toulouse, CNRS, INPT, UPS, France

5Instituto Franco-Argentino para el Estudio del Clima y sus Impactos (UMI IFAECI/CNRS-CONICET-UBA), University of Buenos Aires, Argentina

\section{Corresponding author:}

Kunshan Bao, School of Geography, South China Normal University, China, 55 West Zhongshan Road, Guangzhou 510631, China. Email: ksbao@scnu.edu.cn

\begin{abstract}
A multi-proxy record of Holocene and late-Pleistocene aeolian mineral dust is reconstructed using a combination of geochemical (trace elements), mineralogical and grain-size analyses on cores from the Hani peatland in north-eastern (NE) China. The dust record displays a sharp increase in dust deposition during the late Holocene in comparison to the rest of the Holocene. This trend is in line with climatic records from the Chinese dust source regions and their downwind areas, which generally show an increase in aridity and aeolian activity during the late Holocene. The larger part of the Chinese dust source regions experienced a gradual increase in effective moisture and vegetation cover reaching maxima during the middle Holocene (6.0-8.0 kyr cal. BP) co-occurring with the minima in dust deposition in Hani. These changes in the dust source regions are likely to have been modulated by the variations in the East Asian summer monsoon (EASM), which is the principal mechanism controlling climate in the region. The intensified EASM during the middle Holocene is also likely to have resulted in a sediment recharge at the margin of the Chinese drylands providing additional material and enhancing the atmospheric dust load after the late-Holocene aridification of the region. Combined together, these changes promoted a remobilization of dust sources increasing the amount of material available for transport by the East Asian winter monsoon (EAWM) and the Westerlies. Human activities might also have played a role in the increased dust emissions during the late Holocene, but further research is needed to assess the extent of those impacts at a regional level.
\end{abstract}

\section{Keywords}

atmospheric dust, lithogenic elements, mineralogy, palaeoclimate, particle grain size, peatland Received 4 May 2019; revised manuscript accepted 16 October 2019

\section{Introduction}

Mineral dust plays a significant role on the global climate system, affecting the radiative balance as cloud nuclei, on the chemical composition of the atmosphere and on the marine and terrestrial biogeochemical cycles by supplying nutrients (Harri-son et al., 2001; Maher et al., 2010; Shoenfelt et al., 2018). Not only mineral dust affects climate, but its emission, transport and deposition are also a function of climatic and environmental changes (Lambert et al., 2008; Maher et al., 2010). Palaeo-dust records are windows through which these interactions can be observed and understood. Palaeo-dust archives have been used as indicators of changes in air mass circulation (Ferrat et al., 2012b), wind strength/intensity (De Jong et al., 2007; Fábregas Valcarce et al., 2003; Filipsson et al., 2011), climate variability (Delmonte et al., 2010; deMenocal et al., 2000) and aridity (Marx et al., 2009; Petherick et al., 2009).

The deserts of northern China are among the largest dust source regions on Earth and account for up to $70 \%$ of the total Asian (Zhang et al., 2003) and $25 \%$ of the total global (Ginoux et al., 2004) dust emissions to the atmosphere, respectively. North-eastern (NE) China lies at the northernmost margin of the East Asian summer monsoon (EASM) and is influenced by the interplay between different circulation patterns, mainly the East Asian mon-soon (both the EASM and the East Asian winter monsoon $($ EAWM)) system and the Westerlies. Mineral dust particles from various sources have the potential to be mobilized and transported by these different wind systems. The Siberian High (SH; controlling the intensity of the EAWM) and the Westerlies are the two main circulation systems controlling Asian dust transport, the former is considered to control dust transport in the lower atmosphere $(<3000 \mathrm{~m})$, while the later controls long-range transport at high altitudes $(<5000 \mathrm{~m}$; An et al., 1990; Sun et al., 2001; Zhang et al., 1997). This region is therefore a key, yet overlooked, area for the reconstruction of past dust dynamics and their relationship with climate variability and environmental processes.

Peatlands are important palaeoenvironmental and palaeoclimatic archives which offer a wide range of proxies (geochemical, biological and physical) and chronologies extending as far back as the late Pleistocene. This potentially allows the investigation of the interactions between dust and past environmental and climatic conditions/processes at various time and spatial scales (De Vlee-schouwer et al., 2014a; Ferrat et al., 2012a, 2012b; Kylander et al., 2007; Pratte et al., 2017; Shotyk et al., 2001; Vanneste et al., 2016; Weiss et al., 2002b). While atmospheric dust studies have mainly focused on ombrotrophic peatlands (i.e. atmospherically fed only), a growing number of studies have shown that minerotrophic peat-lands can be used as records of atmospheric deposition of litho-genic elements (Ferrat et al., 2012a, 2012b; Kylander et al., 2007; Weiss et al., 2002b). Peat deposits are widespread in NE China, but have been largely overlooked in dust research, in spite of the relative proximity of some of the largest global dust sources (Bao et al., 2012; Ferrat et al., 2012a, 2012b; Li et al., 2017). 
The aim of this work is to make a palaeoclimatic reconstruction of dust deposition over the last 14.5 kyr at Hani peatland in NE China. Combining physical (ash content, bulk density, grain size and mineralogy) and chemical (trace elements) proxies, the specific objectives of this study are to (1) establish the validity of the Hani peatland as a record of atmospheric mineral dust deposition, (2) quantify the dust accumulation rate $(A R)$ and determine the chronology of the dust events, (3) attempt a preliminary source identification of the mineral particles deposited to this site and (4) reconstruct the paloeoclimatic changes occurring in the region and link them to potential climatic events and controlling factors

\section{Material and methods}

\section{Study site and sampling}

The Hani peatland $\left(42^{\circ} 13^{\prime} \mathrm{N}, 126^{\circ} 31^{\prime} \mathrm{E} ; 900 \mathrm{~m}\right.$ a.s.l.; $18 \mathrm{~km}$ ) is a percolation mire located in the Jilin Province, NE China (Figure 1). It lies in the Longgang volcanic field (LGVF) and is surrounded by numerous volcanic cones, covered by pyroclastic deposits, and crater lakes. The local lithology is mainly composed of alkali basalts, tholeiitic basalts, trachyte and pyroclastic materials of Quaternary age overlying the Archean migmatic group, part of the North China Craton (Bureau of Geology and Mineral Resource of Jilin Province, 1988). The Hani peatland developed by the terrestrialization of a barrier lake that formed after the damming of the Hani River following a volcanic eruption during the latter part of the late Pleistocene (Qiao, 1993). The regional vegetation is composed of a temperate broad leaf-conifer mixed forest. The open areas of the peatland are dominated by Carex lasiocarpa and $C$. limosa, while the hummocks are mainly composed of Sphagnum fuscum and S. magellanicum along with Betula fructicosa and Potentilla fructicosa (Bu et al., 2013; Schröder et al., 2007).

The study area is under a monsoonal climate, characterized by long dry/cold winters, dominated by air masses from the Asian interior, and short moist/cool summers, under the influence of south-easterly winds from the Western Pacific. The region receives mean annual precipitations of around $775 \mathrm{~mm}$ most of which ( $>80 \%)$ falls between May and September via the EASM (Schettler et al., 2006b). The mean annual temperature is $3.4^{\circ} \mathrm{C}$, with monthly averages ranging between $-18.1^{\circ} \mathrm{C}$ and $20.7^{\circ} \mathrm{C}(\mathrm{Schettler} \mathrm{et} \mathrm{al.,}$ 2006b). The EAWM and Westerly winds strongly affect the region during winter and especially spring (Chu et al., 2009) when the breakdown of the SH creates cold fronts (Roe, 2009), that is, conditions favourable for the occurrence of dust storms in spring (Chu et al., 2009; Zhu et al., 2013).

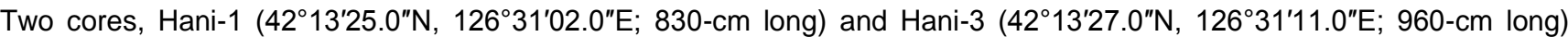
were retrieved from the deepest part, determined by depth prob-ing, of the peatland in October 2012. A monolith was cut (10 $\times 10 \mathrm{~cm}$ width) to sample the upper $50 \mathrm{~cm}$ of the Hani-1 core and a Belarusian peat corer with 5-cm diameter was used to collect deeper sections of both cores. The cores were wrapped in plastic film, transferred into PVC tubes and stored in a freezer $\left(-20^{\circ} \mathrm{C}\right)$. In the laboratory, the cores were sliced fresh at $1-\mathrm{cm}$ intervals for the first $50 \mathrm{~cm}$ and at $2-\mathrm{cm}$ intervals for the rest of the cores. The edges of each subsample were trimmed away, to avoid any con-tamination from the coring process. The thickness of each slice was then measured again to evaluate the loss from the slicing and correct the midpoint depth of each sample.

\section{Age-depth model}

The chronological control of the cores is based on ${ }_{14} \mathrm{C}$ AMS dates. Whenever possible, only aboveground plant macrofossils (mainly Sphagnum stems, Carex seeds and Ericaceae leaves) were selected based on a protocol developed by Mauquoy et al. (2004), in order to ensure a better accuracy of dates (Table 1). In some samples, bulk peat material was dated as insufficient material was found. A total of 15 samples (3 for Hani-1 and 12 for Hani-3) were submit-ted to the Beta Analytic facility (Florida, US) for AMS radio- carbon dating. The radiocarbon dates were calibrated using the InterCal13 Northern Hemisphere terrestrial calibration curve (Reimer et al., 2013) integrated in the BACON package (Blaauw and Christen, 2011). The model was constrained with the surface sample of the cores corresponding to the age of sampling (2012 CE). A composite age-model was reconstructed by aligning Hani- 1 and Hani-3 cores based on the obtained radiocarbon ages and the ash content.

\section{Bulk density, ash content and grain-size analyses}

The bulk density of the samples was obtained by subsequently weighting a subsample fresh and after freeze-drying. The ash content, used as a surrogate of the mineral matter content, was measured on the same subsamples by loss-on-ignition, that is, combusting at $550^{\circ} \mathrm{C}$ for $6 \mathrm{~h}$ to remove all the organic matter (Chambers et al., 2011). Prior to analysis, a selection of ash sam-ples (135), resulting from the ash content analyses, were submit-ted to a $1 \mathrm{M} \mathrm{HCl}$ treatment to remove carbonates and sulphates formed during the ashing process. While thermal combustion is an effective way of removing organic matter, grain aggregates may form during the process depending on sample lithology and mineral content (Murray, 2002). The grain-size distribution was determined by laser diffraction on the acid-insoluble inorganic fraction of bulk samples using a laser-optical particle size analyser (Malvern Masterizer-2000, Nanjing Institute of Geography and Limnology, Chinese Academy of Sciences (NIGLAS, China)), after the addition of $10 \mathrm{~mL} 0.05 \mathrm{~mol} \mathrm{L-1}$ sodium hexametaphos-phate $\left(\mathrm{NaPO}_{3}\right)$ and being subjected to a short ultrasound treatment $(5 \mathrm{~min})$ to separate particles. The grain-size distribution of the samples was characterized by 75 size classes. The instrument has a range of $0.02-2000 \mu \mathrm{m}$ and an accuracy of $<3 \%$ from repeated measurement errors.

\section{Mineralogical analyses}

X-ray diffraction (XRD) analyses were performed at NIGLAS, using a Malvern Panalytical XRD system (X'Pert3 Powder) to determine the mineralogy of the ash fraction of selected samples $(n=30)$. Combustion of peat samples at temperature greater than $450^{\circ} \mathrm{C}$ has been shown to be the most effective method for removing organic matter for XRD analyses, with minimal altera-tion of the mineralogy, except for clays (Sjöström et al., 2019). Prior to analysis, the samples were washed with water to remove the soluble salts (Sjöström et al., 2019). The step scanning size was from $10^{\circ}$ to $70^{\circ}$ with a step size of $0.02^{\circ}$ and counting time of $2 \mathrm{~s}$ per steps.

\section{Major and trace elements analyses}

A total of 350 samples in Hani-1 and 220 in Hani-3 were processed for elemental geochemistry. Samples were freeze-dried and powdered using an agate mortar and pestle. For Hani-1, about $200 \mathrm{mg}$ of dried peat powder was placed in Teflon ${ }^{\circ}$ vessels $(50$ $\mathrm{mL}$ ), and $3 \mathrm{~mL}$ of $\mathrm{HNO}_{3}$ and $1 \mathrm{~mL}$ of $\mathrm{HF}$ was added to them. Then the vessels were closed and placed in an Acid Digestion Bomb (ADB; placed inside a steel jacket). Then the ADB were placed in an oven for $48 \mathrm{~h}$ at $180^{\circ} \mathrm{C}$. After cooling down the ADB, the solutions were evaporated to near dryness on a hotplate. Then, the remaining solution were diluted with $2 \% \mathrm{HNO}_{3}$ and transferred 
to centrifuge tubes. For Hani-3 as well as the $<63 \mu \mathrm{m}$ fraction of local soils, approximately $100 \mathrm{mg}$ of powdered samples were acid digested until complete dissolution, using a series of steps $\left(\mathrm{HNO}_{3}\right.$ and $\mathrm{HF}$, then $\left.\mathrm{H}_{2} \mathrm{O}_{2}\right)$ in Savillex ${ }^{\circledR}$ beakers on a hot plate following De Vleeschouwer et al. (2014b). Selected major ( $\mathrm{Na}, \mathrm{Mg}, \mathrm{Al}, \mathrm{K}, \mathrm{Ca}, \mathrm{Fe}$ and $\mathrm{Mn}$ ) and trace (Ti, Sr, Rb, Zr, Sc, Ba, Y, Cs, REE and Th) element measurements were completed on an Agilent Technologies 7500ce Q-ICP-MS at Observatoire Midi-Pyrénées in Toulouse, France as well as NIGLAS, in Nanjing in 2018 (also using an Agilent Technologies 7500ce QICP-MS) for core Hani-3 and in Guiyang, in 2013 (ELAN DRC-e Q-ICP-MS) for core Hani-1. The analytical performance was assessed using reference materials: GBW-07603 (bush leaves and twigs), GBW-07358 (stream sediments), NIST SRM1515 (apple leaves) and NIST SRM1547 (peach leaves). Replicate analyses were gen-erally within 10\% of each other. The blanks for all elements considered here are $<0.01 \%$.

\section{Statistical analyses}

A principal component analysis (PCA) was performed on the ele-ment ARs using SPSS 21.0 .0 software to help identify the sources and processes affecting the distribution of the chemical elements in both peat profiles. A PCA reduces the dimension of a data set and explain as much variability as possible with fewer compo-nents (Jolliffe, 2002; Reimann et al., 2008). The PCA was exe-cuted in correlation mode on previously log transformed $\left(\log _{10}\right)$ and standardized (z-scores) data to avoid scaling effects, using a varimax rotation which is a fixed orthogonal rotation that maxi-mizes the loadings of the variables on the components (Eriksson et al., 1999). The $z$-scores were calculated as $\left(X_{i}-X_{\text {avg }}\right) / X_{\text {std }}$, where $X_{i}$ is the variable (i.e. concentration of the element), while $X_{\mathrm{avg}}$ and $X_{\text {std }}$ are the series average. A hierarchal clustering analy-sis (HCA) was applied to the grain size data set using the classes as variables in SPSS 21.0.0. The HCA was used to group together samples with similar grain-size distributions. 


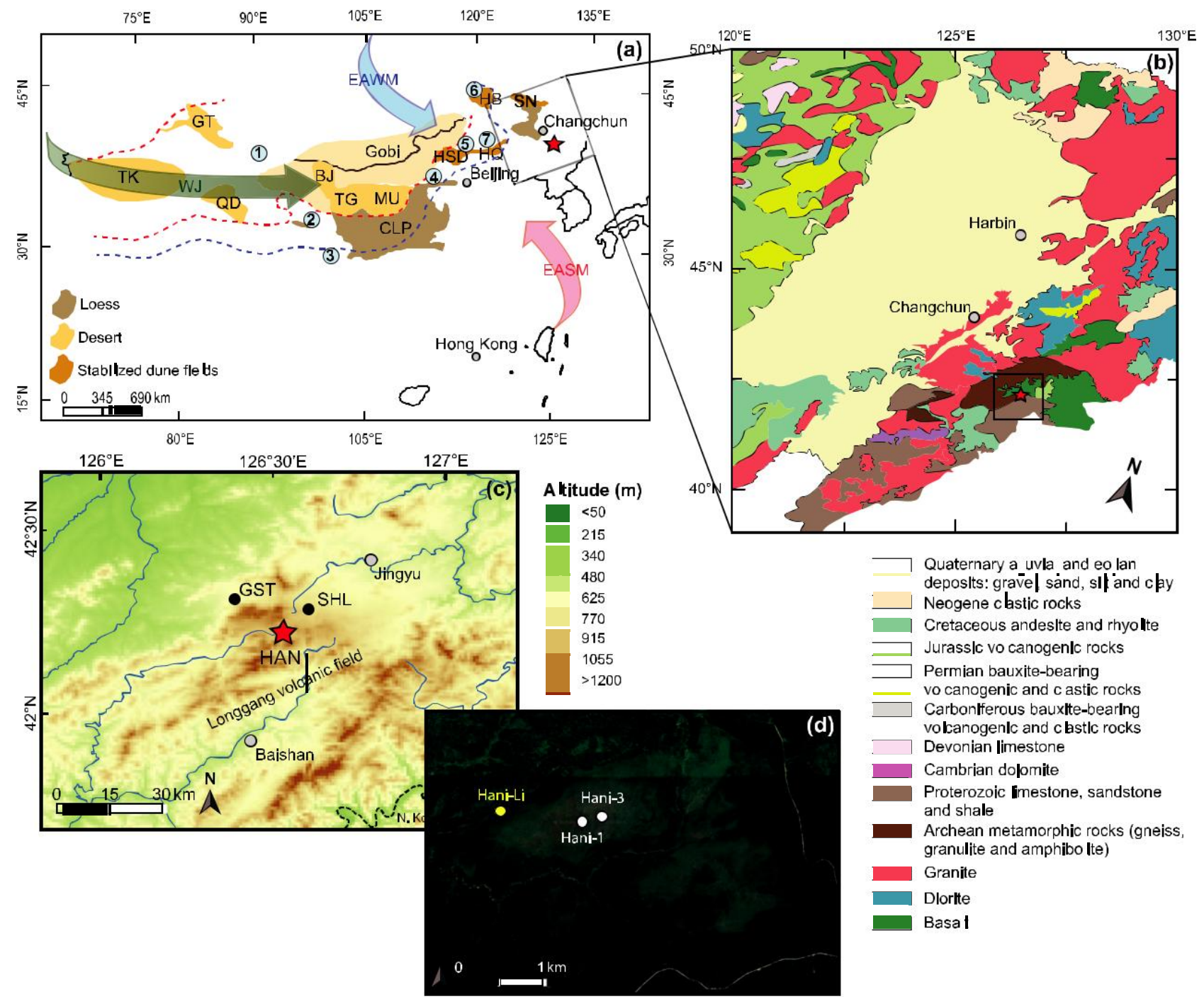

Figure 1. (a) Location of the study region in China and relative location of the records discussed in the manuscript: (1) Lake Tuolekule (An et al., 2011), (2) Lake Qinghai (Shen et al., 2005), (3) Hongyuan peatland (Ferrat et al., 2012a, 2012b), (4) Lake Dahai (Xiao et al., 2004),

(5) Lake Xiarinur (Xu et al., 2018), (6) Lake Hulun (Wen et al., 2010) and (7) Lake Dali (Goldsmith et al., 2017). Deserts and stabilized dune fields of China: Taklamakan (TK), Gurbantunggut (GT), Qaidam (QD), Badain Jaran (BJ), Tengger (TG), Mu Us (MU) deserts; Chinese Loess Plateau (CLP); Onqin Daga (OD), Hulun Buir (HB), Horqin (HQ) and Songnen (SN) dune fields. Red dashed line: approximative modern limit of arid China; blue dashed line: approximative modern limit of semi-arid China. (b) Geological map of the study area (modified from Gu et al. (2015) and Commission for the Compilation of the Geological Map of China (1990); (c) location of the Hani peatland and of the records in the LGVF discussed in the text: Lake Sihailongwan (SHL; Schettler et al., 2006b), Gushantun (GST; Li et al., 2017). Grey dots: location of cities and towns in each panel. The topographic map was created with QGIS $\circledast$ using gridded xyz data from the SRTM 30PLUS V11 global database (Becker et al., 2009). (d) Satellite image of the Hani peatland (source: Google Earth) showing the location of Hani-1 and Hani-3 cores (white dots) and of a core from Li et al. (2017) (yellow dot). 
Table 1. Results of ${ }_{14} \mathrm{C}$ AMS measurements, calibrated age ranges and description of samples.

Sample Depth (cm) Laboratory number $\quad{ }_{14} \mathrm{C}$ age (BP)2 $\sigma$ range (yr cal. BP) Material dated

\begin{tabular}{lllrcl}
\hline HANI1 B8 & 60.5 & BETA-499811 & $270 \pm 30$ & $152-435$ & Bulk sample \\
HANI1 D17 & 183.0 & BETA-499312 & $1850 \pm 30$ & $1715-1865$ & Bulk sample \\
HANI1 J21 & 491.0 & BETA-499813 & $7410 \pm 30$ & $8178-8323$ & Bulk sample \\
HANI3 B7 & 56.9 & BETA-499800 & $450 \pm 30$ & $471-536$ & Sphagnum spp. stems/leaves \\
HANI3 C22 & 122.6 & BETA-499801 & $1020 \pm 30803-1042$ & Sphagnum spp. stems, Carex seeds \\
HANI3 D25 & 177.3 & BETA-499802 & $1710 \pm 30$ & $1553-1699$ & Brown mosses \\
HANI3 E6 & 211.5 & BETA-499804 & $2350 \pm 30$ & $2324-2464$ & Sphagnum spp. stems \\
HANI3 G12 & 322.8 & BETA-499805 & $4080 \pm 30$ & $4445-4806$ & Carex seeds \\
HANI3 I10 & 418.3 & BETA-499806 & $4540 \pm 30$ & $5053-5314$ & Sphagnum spp. stems, Carex seeds \\
HANI3 J21 & 490.8 & BETA-499807 & $7340 \pm 30$ & $8033-8276$ & Carex seeds \\
HANI3 L20 & 589.0 & BETA-499808 & $8560 \pm 30$ & $9495-9550$ & Ericaceae leaves, seeds \\
HANI3 M21 & 643.0 & BETA-499809 & $9270 \pm 30$ & $10,297-10,598$ & Sphagnum spp. stems, Ericaceae leaves, brown mosses stems \\
HANI3 O11 & 722.0 & BETA-435994 & $10,260 \pm 30$ & $11,831-12,144$ & Bulk sample \\
HANI3 Q20 & 840.0 & BETA-435995 & $11,430 \pm 30$ & $13,181-13,358$ & Bulk sample \\
HANI3 S20 & 939.0 & BETA-499810 & $12,280 \pm 40$ & $14,041-14,456$ & Leaves, seeds, conifer needles \\
\hline
\end{tabular}

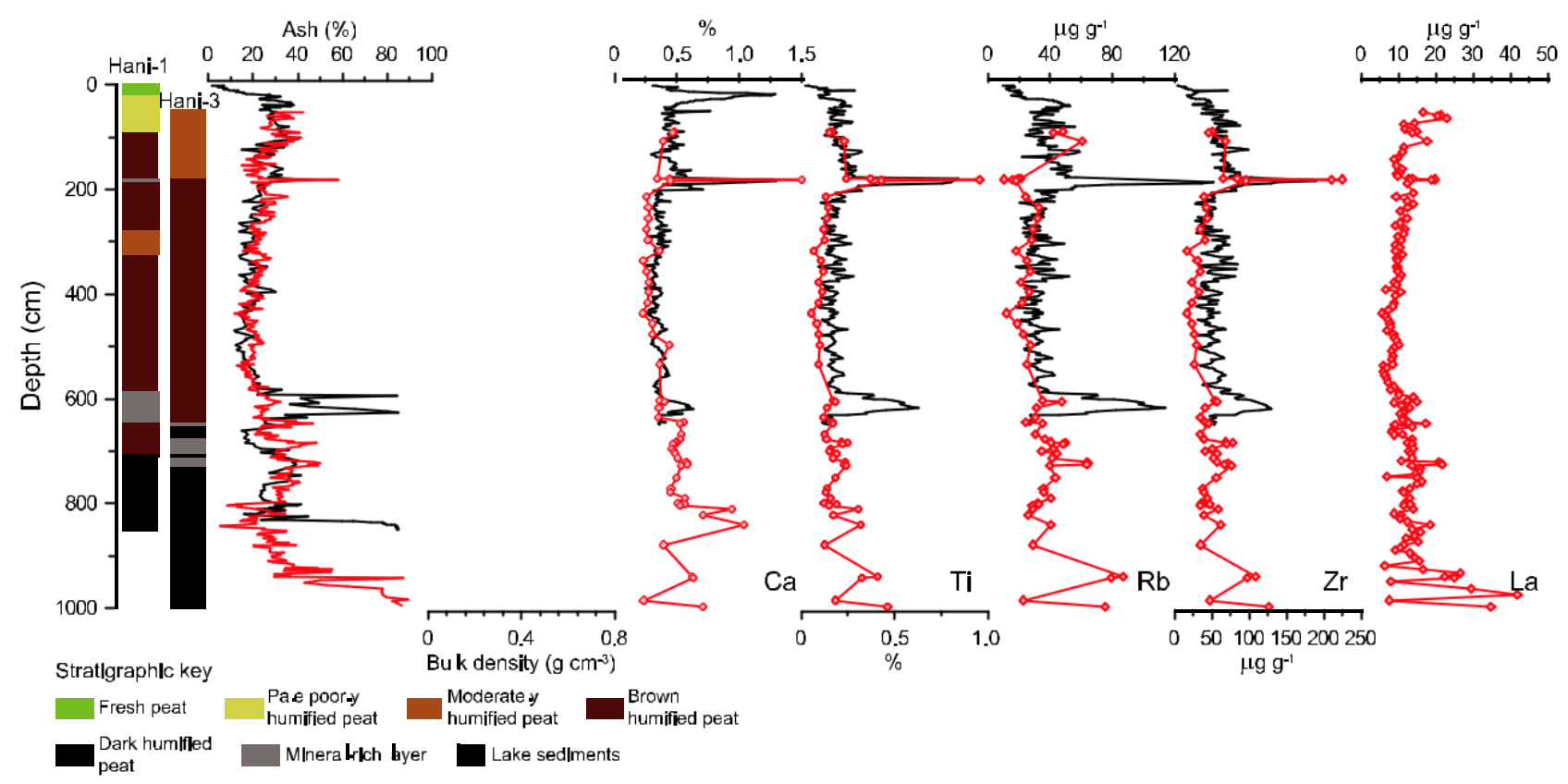

Figure 2. Lithostratigraphy of the Hani-1 and Hani-3 cores. Depth records of ash content, bulk density and concentrations of selected elements in Hani-1 (black curves) and Hani-3 (red curves). 


\section{Results}

Core stratigraphy, bulk density and ash content

The stratigraphy, ash content, bulk densities and elemental concentrations of the peat cores are shown in Figure 2. The plant matter is generally well preserved; however, some variations between darker more humified peat and paler less humified peat is observed. The plant composition is generally dominated by sedges with Sphagnum spp. present in various proportions. In Hani-1, from 0 to $21 \mathrm{~cm}$, fresh undecomposed peat is found. From 21 to $100 \mathrm{~cm}$, the peat is yellowish and poorly humified. A more humified and brown peat is found between 100 and $589 \mathrm{~cm}$ interspersed with a mineral layer around $180 \mathrm{~cm}$ and a thick less humified pale brown peat containing well preserved plants at $290-330 \mathrm{~cm}$. There is a prominent mineral-rich layer (containing coarse sands and clay) from 589 to $639 \mathrm{~cm}$. In the deeper section between 639 and $830 \mathrm{~cm}$, the peat is darker and very humified. In Hani-3, the peat is moderately humified, light brown and con-tains well preserved plants remain between 50 and $180 \mathrm{~cm}$, where a mineral-rich layer is found at $180-185 \mathrm{~cm}$. From 185 to $600 \mathrm{~cm}$, the peat composition is rather uniform being brown and more humified. Between 600 and $931 \mathrm{~cm}$, the peat is mainly dark brown, characterized by a greater degree of humification and contains distinct mineral-rich layers at 645-649, 683-691 and 723-729 cm. Below $930 \mathrm{~cm}$, the core is composed of silt-rich grey lake sediments.

The bulk density of the peat in Hani- 1 and Hani-3 cores ranges between 0.02 and $0.66 \mathrm{~g} \mathrm{~cm}-3$ and 0.05 and $0.28 \mathrm{~g} \mathrm{~cm}-3$ in Hani-1 and Hani-3, respectively (Figure 2). Hani-1 displays mineral-rich layers with values of $0.23-0.34 \mathrm{~g} \mathrm{~cm}-3$ between 502 and $489 \mathrm{~cm}, 0.48-0.58 \mathrm{~g} \mathrm{~cm}-3$ from $571-578 \mathrm{~cm}$ and $0.26-0.66 \mathrm{~g} \mathrm{~cm}-3$ at $601-622 \mathrm{~cm}$ of depth. Comparatively, mineralrich layers in Hani-3 (centred around 647, 685, 727, 759 and $180.5 \mathrm{~cm}$ ) do not display greater bulk densities.

The ash content varies between $2 \%$ and $85 \%$ in Hani-1, while it ranges between $5 \%$ and $58 \%$ in Hani-3 (Figure 2 ). Hani-1 dis-plays a sharp increase in ash content reaching up to $85 \%$ between 583 and $639 \mathrm{~cm}$, within the mineral-rich layer. Peaks in ash con-tent values (32-50\%) are observed between 600 and $800 \mathrm{~cm}$ of depth as well as at $180.5 \mathrm{~cm} \mathrm{(58 \% )} \mathrm{in} \mathrm{Hani-3.}$ The ash content is lower and more stable between 200 and $600 \mathrm{~cm}$ in both cores, averaging $19 \pm 4 \%$ and $21 \pm 4 \%$ in Hani- 1 and Hani-3, respec-tively. Both cores also display an increase in ash content from $100 \mathrm{~cm}$ towards the surface reaching up to $40 \%$.

\section{Age-depth model}

The Hani-1 and Hani-3 cores display very similar ages and age- depth models (Table 1 and Figure 3) between 60 and 490 $\mathrm{cm}$. Samples from the bottom of Hani-1 (deeper than $500 \mathrm{~cm}$ ) core were not available (lost during transfer between Guiyang and Nanjing) for radiocarbon dating, so only the section of 500-930 cm from Hani-3 was used in the reconstruction of that part of the age-depth model and of the dust record. The composite age model (Figure 3 ) shows that AR is relatively constant from peat initiation at $930-490 \mathrm{~cm}$ of depth averaging $0.07 \mathrm{~cm} \mathrm{yr}-1$, decreasing to $0.03 \mathrm{~cm}$ yr-1 between 490 and $410 \mathrm{~cm}$ (Figure 3). From 410 to $180 \mathrm{~cm}$, the $\mathrm{AR}$ is $0.06 \mathrm{~cm} \mathrm{yr-1}$ and then increases around $0.08 \mathrm{~cm} \mathrm{yr}-1 \mathrm{from} 180 \mathrm{~cm}$ towards the top.

\section{Grain size and mineralogy}

The mean particle size in the Hani record ranges between 11.6 and $257 \mu \mathrm{m}$ with an average of $18.6 \mu \mathrm{m}$, while the median grain size range is $10-18.7 \mu \mathrm{m}$ (average: $10.5 \pm 1.9 \mu \mathrm{m})$. The samples are dominated by silt-size particles $(4-63 \mu \mathrm{m})$, but clay $(<2 \mu \mathrm{m})$ and sand $(>63 \mu \mathrm{m})$ particles are present in various proportions in every samples (Figure 4). However, the fact that the samples were submitted to loss-on-ignition prior to analysis might have resulted in a compaction of the clays, which means the clay fraction might be underrepresented. The cluster analysis identified three different clusters with distinct enough grain-size distributions (Figure 4). As all samples display a main mode in the silt fraction, the separa-tion of the three clusters is mainly based on the presence of differ-ent modes (unimodal, bimodal and polymodal) in the grain-size distribution. Cluster 1 ( $n=74$; composed of three subgroups) represents samples with relatively unimodal grain-size distribu-tions. Cluster 2 ( $n=35$; two subgroups) corresponds to samples presenting a fine subpopulation $(<1 \mu \mathrm{m})$ in their distribution. The distinction of the two subgroups is mainly based on the amplitude of the main mode. Cluster 3 ( $n=26$; five subgroups) includes samples displaying a coarse subpopulation ( $>100 \mu \mathrm{m})$. The sepa-ration of the subgroups in cluster 3 is mainly based on the sand and clay content.

The semi-quantitative estimates of the mineral composition of the ash samples are shown in Table 2 . The XRD analyses on the selected core samples show that quartz is the dominant min-eral in most samples along with phyllosilicates, plagioclase and K-feldspars (Figure 4). A few samples display greater amounts of plagioclase feldspars, especially at 180.5, 182.7 (1700-1760 cal. BP) and $635.0 \mathrm{~cm}$ of depth, where they exceed quartz.

\section{Elemental concentrations and PCA analysis}

The lithogenic elements display similar concentration patterns between themselves (Figure 2). Although different digestion methods were used, apart from the mineral layers in Hani-1, the two cores show very similar elemental concentrations. Concentrations of lithogenic elements in both cores are slightly higher below $600 \mathrm{~cm}$ of depth and are generally at their lowest level between 600 and $400 \mathrm{~cm}$. Both cores also display a peak in the concentration of most elements, apart from Cs and Rb, around $180 \mathrm{~cm}$.

The results of the PCA analyses are shown in Figure 5. In both cores, two principal components (PC) were extracted, explaining $92.4 \%$ and $96.0 \%$ of the total variance of Hani-1 (12 chemical elements) and Hani-3 (30 chemical elements), respectively. The first PCs account for $68.0 \%$ and $60.8 \%$ of variance in Hani-1 ( Na, Li, Al, Rb, Ba, Ti, Mg, Zr, K) and Hani-3 (REE (except Eu), Cs, Rb, Y, $\mathrm{Sc}, \mathrm{Al}, \mathrm{Th}, \mathrm{K}$ and $\mathrm{Mg}$ ), respectively. PC2 explains $24.4 \%$ of the total variance in Hani-1 (Ca, Sr, $\mathrm{Fe}$ ) and $35.2 \%$ in $\mathrm{Hani}-3$ (Ca, $\mathrm{Sr}$, $\mathrm{Ti}, \mathrm{Zr}, \mathrm{Na}, \mathrm{Eu}, \mathrm{Ba}$ and $\mathrm{Fe}$ ). The fractionation of the com-munality, that is, the variance of each element $\mathrm{AR}$ explained by the extracted components, is shown in Figure 5. The discrepan-cies between the PCA results of Hani-1 and Hani-3 are because of a combination of factors. The fact that Ca-AR, Sr-AR and Fe-AR load on a separate PC in Hani- 1 is explained by the inclusion of the first $50 \mathrm{~cm}$ of the core in the analysis. The $\mathrm{Ca}$, Sr and Fe dis-play a sharp increase in concentrations between 10 and $30 \mathrm{~cm}$ (Figure 2). Furthermore, the large mineral layer in Hani-1 is likely driving a large part of the variance of the other elements. If these two sections of Hani-1 core are removed, $\mathrm{Ti}, \mathrm{Na}$ and $\mathrm{Zr}$ load on the same $\mathrm{PC}$ as $\mathrm{Ca}$ and $\mathrm{Sr}$ suggesting similar controlling factor as in Hani-3. Another factor to consider is the fact that the majority of the elements loading on PC1 in Hani-3 core were not analysed in Hani-1, namely, REEs and Cs. This likely means that REEs along with some other lithogenic elements (Y, Cs, Rb, Sc and Al) are controlled by different underlying processes than the other elements. 


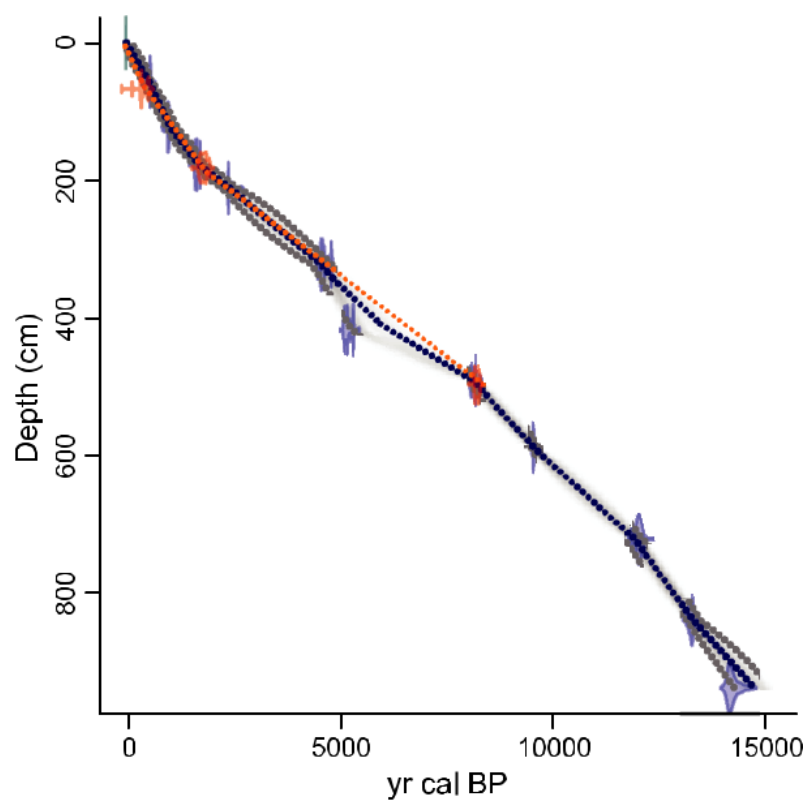

Figure 3. Age-depth models for Hani peatland constructed using the BACON software (Blaauw and Christen, 2011). The grey areas encompass all possible age-depth models while the dotted grey lines indicate the $95 \%$ confidence intervals. The orange and dark blue line corresponds to the weighted mean age of each modelled sample for Hani-1 and Hani-3, respectively. Orange (Hani1) and blue (Hani-3) symbols represent the calendar age distribution of the ${ }_{14} \mathrm{C}$ AMS dates. 

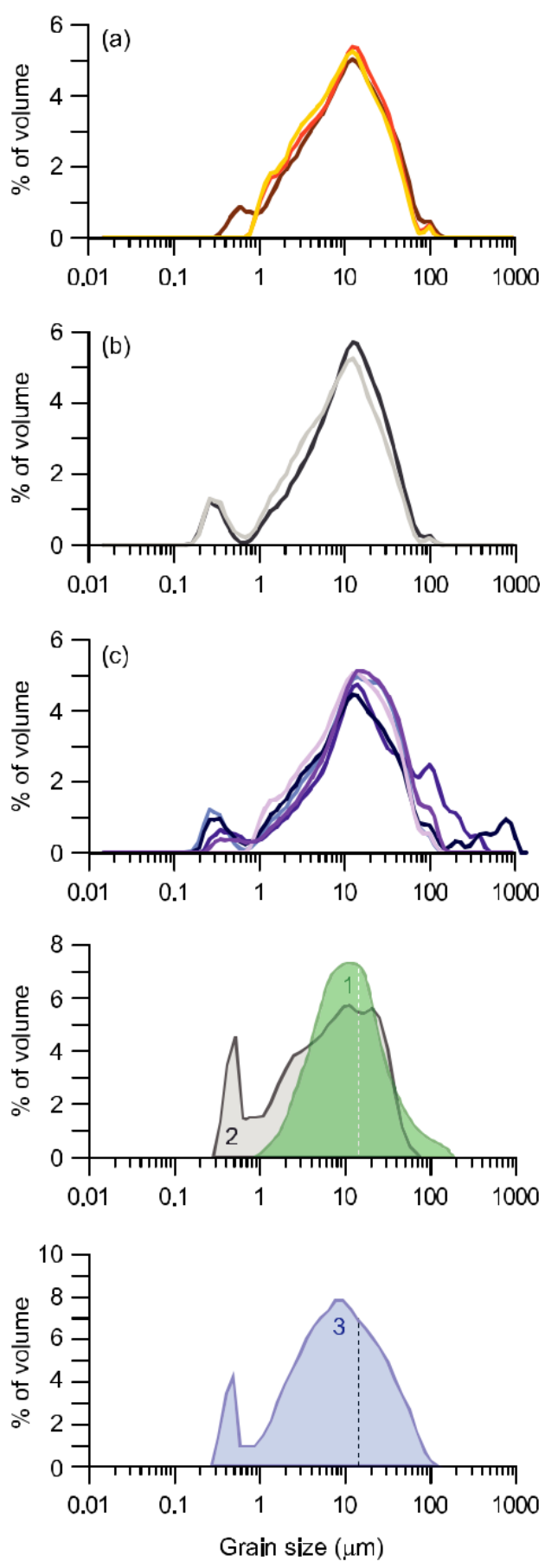

Figure 4. Grain-size distributions of the mineral fraction in Hani samples obtained from the clustering analysis ((a) Cluster 1,

(b) Cluster 2 and (c) Cluster 3). Each grain-size distribution pattern corresponds to a representative sample selected from the subgroups composing each cluster. Comparison with the distribution of present-day dust samples from (1) passive dust collectors in the Changbai Mountains (average; Li et al., 2017)

(2) dust sample from a dust event collected on snow in 2002 in the Longgang region (Chu et al., 2009) and (3) sediment sample selected from a sediment core in lake Sihailongwan (Chu et al., 2009).

\section{Dust flux}

As mentioned in section 'Age-depth model', given the similarity of the radiocarbon ages, ash contents and the lithogenic element concentrations in Hani-1 and Hani-3 cores, a composite dust record was reconstructed. The dust AR, that is, dust flux ( $\mathrm{g} \mathrm{m}-2 \mathrm{yr}-1)$, was calculated using the sum of REE (excluding Eu, as it displays high loading factors on PC2) applying the following for-mula

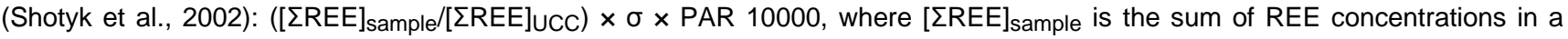
sample, [ $\Sigma R E E]$ ] $c c$ is the sum of REE concentrations in the upper continental crust (143.0 mg kg-1; Wedepohl, 1995), $\sigma$ is the sample's bulk density $\left(\mathrm{g} \mathrm{cm}_{-3}\right)$ and PAR is the peat accumulation rate $(\mathrm{cm} \mathrm{yr}-1)$. REEs were selected on the basis that they behave conservatively and show the highest loading on PC1 (Figure 5). Different elements and references will yield very similar trends and timing, but different estimates of dust ARs (Kylander et al., 2016; Shotyk et al., 2002). For this reason, the dust flux was also reconstructed using $\mathrm{Ti}$ as its high loading on PC2 in Hani-3 and PC1 in Hani-1 (Figure 5) suggests that local sources contribute significatively to its record at times (Figure $6 \mathrm{~b}$ and $\mathrm{c}$ ). The top $500-\mathrm{cm}$ dust flux reconstruction (last $8 \mathrm{kyr}$ cal. BP) is based on an average of Ti concentrations in Hani- 1 and Hani-3, while the bot-tom $500 \mathrm{~cm}(8-14.5 \mathrm{kyr}$ cal. BP) is based on Hani-3 core only. 
Table 2. Mineralogical composition of selected samples.

\begin{tabular}{|c|c|c|c|c|c|}
\hline $\begin{array}{l}\text { Depth } \\
(\mathrm{cm})\end{array}$ & Quartz & $\begin{array}{c}\text { K- } \\
\text { Feldspar }\end{array}$ & $\begin{array}{l}\text { Plagioclase } \\
\text { Feldspar }\end{array}$ & $\begin{array}{l}\text { Phyllo- } \\
\text { silicate }\end{array}$ & Pyroxene \\
\hline 58.2 & $\ldots$ & • & • & •• & \\
\hline 64.7 & •• & • & .• & •• & \\
\hline 104.0 & •• & tr & • & •• & \\
\hline 126.5 & •• & $\operatorname{tr}$ & • & •• & \\
\hline 162.7 & ... & $\operatorname{tr}$ & • & .• & \\
\hline 180.5 & •• & - & ... & • & - \\
\hline 182.7 & •• & • & ... & • & • \\
\hline 228.4 & $\cdots$ & • & • & •• & \\
\hline 241.0 & •• & .• & • & •• & \\
\hline 284.1 & •• & • & • & •• & \\
\hline 336.7 & •• & • & • & •• & \\
\hline 382.5 & ... & - & • & .• & \\
\hline 408.2 & •• & $\operatorname{tr}$ & • & •• & \\
\hline 463.0 & .• & • & • & ... & \\
\hline 507.0 & $\cdots$ & •• & $\operatorname{tr}$ & •• & \\
\hline 579.0 & .. & - & - & ... & \\
\hline 603.0 & •• & • & • & •• & \\
\hline 613.0 & •• & • & • & .• & \\
\hline 635.0 & $\bullet$ & •• & .• & •• & $\operatorname{tr}$ \\
\hline 645.0 & ... & • & • & • & \\
\hline 685.0 & $\cdots$ & • & • & •• & \\
\hline 723.0 & .. & .. & .. & • & $\mathrm{tr}$ \\
\hline 759.0 & $\bullet$ & • & • & $\cdot$ & \\
\hline 803.0 & ... & tr & • & •• & \\
\hline 847.0 &.. & .. & .. & • & \\
\hline 873.0 & $\cdots$ & $\operatorname{tr}$ & • & $\cdot$ & \\
\hline 911.0 & •• & • & • & •• & \\
\hline 917.0 & ... & tr & • & •• & \\
\hline 931.0 & ... & $\operatorname{tr}$ & • & .• & \\
\hline 947.0 & $\cdots$ & • & .• & •• & \\
\hline 987.0 & ... & tr & •• & •• & \\
\hline
\end{tabular}

...: >50\%; •.: 20-50\%; •: 5-20\%; tr: <5\%.

The section composed of lake sediment is not reconstructed in terms of dust deposition as it was probably dominated by runoff that is likely to have overprinted the atmospheric dust signal. If we exclude the lake sediments, Hani peatland represents a $14.5-\mathrm{kyr}$ record of mineral dust deposition. Between 14.5 and $12.0 \mathrm{kyr}$ cal. BP, the dust flux, based on $\Sigma$ REE, oscillates around $25 \mathrm{~g} \mathrm{~m}-2 \mathrm{yr}-1$ and displays a peak centred around $11.8 \mathrm{kyr}$ cal. BP (Figure 6b). From 11.7 until $8.0 \mathrm{kyr}$ cal. BP, dust deposition shows a gradually decreasing pattern from 35 to $10 \mathrm{~g} \mathrm{~m}-2 \mathrm{yr}-1$ interspersed with a few small peaks. The lowest dust deposition rates are observed between 8.0 and $6.0 \mathrm{kyr}$ cal. BP averaging $6.3 \pm 1.3 \mathrm{~g} \mathrm{~m}-2 \mathrm{yr}-1$. The dust flux increases sharply around $5.7 \mathrm{kyr}$ cal. BP reaching a peak of $35 \mathrm{~g} \mathrm{~m}-2 \mathrm{yr}-1$ at around $5.1 \mathrm{kyr}$ cal. BP. Between 4.5 and $2.2 \mathrm{kyr}$ cal. BP, dust deposition remains relatively stable averaging $20.7 \pm 4.7 \mathrm{~g} \mathrm{~m}-2 \mathrm{yr}-1$. The dust flux increases again after $2.0 \mathrm{kyr}$ cal. BP display-ing high variability with values between 368 (1.8 kyr cal. BP) and $15 \mathrm{~g} \mathrm{~m}-2 \mathrm{yr}-1$. The dust flux, based on Ti, displays very similar tim-ing and generally closely matches the dust flux values from $\Sigma$ REE. A few peaks, showing higher values than for the $\Sigma$ REE-based flux, are present before $12.0 \mathrm{kyr}$ cal. $\mathrm{BP}$, with values over $50 \mathrm{~g} \mathrm{~m}-2 \mathrm{yr}-1$, and especially around $1.7 \mathrm{kyr}$ cal. BP, reaching $420 \mathrm{~g} \mathrm{~m}-2 \mathrm{yr}-1$. 
(a)

Hani 1

Fraction of communality

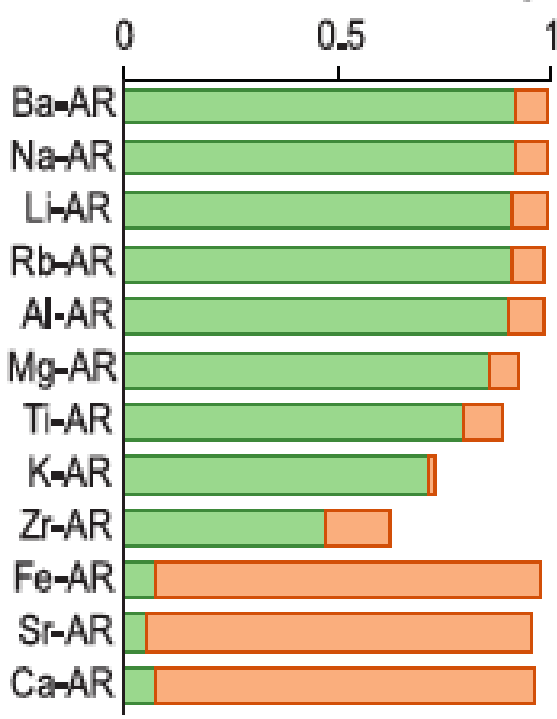

$\square \mathrm{PC} 1 \square \mathrm{PC} 2$

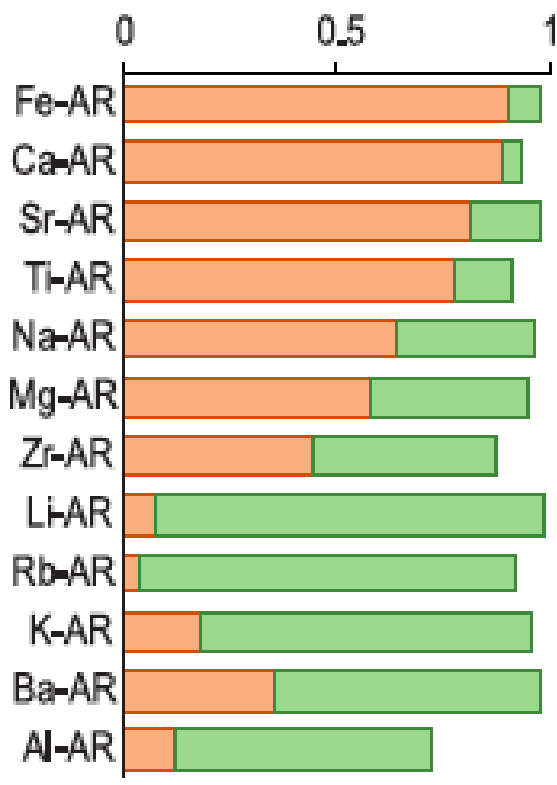

$\square \mathrm{PC} 1 \square \mathrm{PC} 2$ (b)

Hani 3
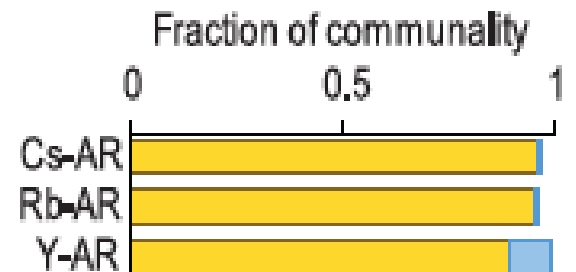

LURAR

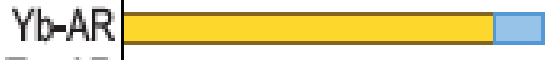

Tm-AR $\square$

EraAR $\square$

Th-AR $\square$

Ho-AR $\square$

Th-AR $\square$

Dy-AR

LaAR $\square$

Pr-AR $\square$

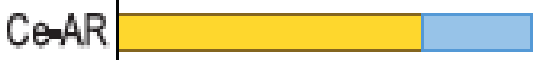

$\mathrm{Tb}-\mathrm{AR}$

Nd-AR $\square$

Gd-AR $\square$

Sm-AR $\square$

SC-AR $\square$

Mg-AR $\square$

Al-AR

STAAR

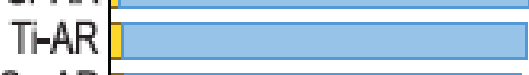

CaAR

ZTFAR

NaAR

EULAR

Ba-AR

Fe-AR

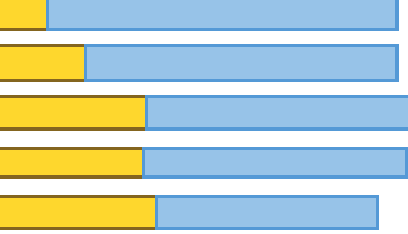

\section{${ }_{\square P C 1} \square \mathrm{PC} 2$}

Figure 5. Fractionation of the communality of the accumulation rate of each element after extraction by principal component analysis for (a) Hani-1 (top PCA including top $50 \mathrm{~cm}$ and mineral layer; bottom: PCA excluding top $50 \mathrm{~cm}$ and mineral layer) and (b) Hani-3 (the communality corresponds to the total variance of an element explained by the extracted components).

\section{Discussion}

Trophic status of the peat and major processes controlling the geochemical signal

The trophic status of a peatland might affect how inorganic con-stituents are archived in a geochemical record. The ash content in Hani averages $24-26 \%$ in both cores, in agreement with values found in other Chinese peatlands $(>10-25 \%$; Bao et al., 2010; Ferrat et al., 2012a, 2012b; Wei et al., 2012) but higher than values typically found in ombrotrophic peats (generally $<5 \%$; Sapkota et al., 2007; Shotyk et al., 1998; Tolonen, 1984; Weiss et al., 2002a). Such high ash contents combined with the fact the Hani peatland is Carex-dominated, generally indicative of mineral-rich conditions, are usually typical of a minerotrophic nature. However, given the relative close proximity of some of the largest global dust sources, peatlands of the region receive greater dust deposition which, therefore, results in greater ash contents (Ferrat et al., 2012b; Pratte et al., 2018). Pore-water electrical conductivity in the section of the peatland where the cores were collected is low (45-93 $\mu \mathrm{S})$, suggesting very limited dissolved materials, while the $\mathrm{pH}(4.2-5.1)$ and $\mathrm{C} / \mathrm{N}$ ratios (18-29) are indicative of mesotrophic to oligotrophic conditions (Schröder et al., 2007). Calcium and strontium concentrations have been extensively been used as trophic indicators in peat (Shotyk, 1997; Steinmann and Shotyk, 1997). Ca and Sr concentrations display a slight increase with depth, which could indicate vertical migration fol-lowing mineral dissolution. However, values increase less than twofold from $0.27 \pm 0.08 \%$ and $45.9 \pm 15.3 \mu \mathrm{g} g-1$ for $\mathrm{Ca}$ and $\mathrm{Sr}$, respectively, between 25 and $650 \mathrm{~cm}$ to $0.57 \pm 0.23 \%$ and $87.9 \pm 27.9 \mu \mathrm{g} \mathrm{g}-1$ below $650 \mathrm{~cm}$, which is far lower than the 3- to 16-fold increase observed in some minerotrophic peatlands (Pratte et al., 2017; Steinmann and Shotyk, 1997). Taken together, this evidence suggests that mineral dissolution and element remobilization is limited in Hani peatland and hence it can be used as a geochemical dust archive. The PCAs were performed in order to identify chemical ele-ments displaying similar 
behaviour and hence being controlled by the same processes. The fact that when including the top $50 \mathrm{~cm}$ of Hani-1 core, Ca-AR, Sr-AR and Fe-AR load on a different com-ponent (Figure 5; PC2) suggests that they are partially affected by diagenetic processes, such as changes in redox conditions and vertical migration (Steinmann and Shotyk, 1997). However, for the second PCA analysis on Hani-1 and the one on Hani-3, other elements load on the same PC, namely, $\mathrm{Na}, \mathrm{Ti}, \mathrm{Zr}$ and $\mathrm{Mg} \mathrm{ARs}$ in Hani-1 and Ti, Na, Zr, $\mathrm{Eu}$ and $\mathrm{Ba}$ ARs on Hani-3. This is indica-tive that other processes are affecting the geochemical record of these elements, including $\mathrm{Ca}$ and $\mathrm{Sr}$. Local rocks and deposits are of volcanic origin and rich in plagioclase feldspars (enriched in Na (albite) and $\mathrm{Ca}$ (anorthite) and $\mathrm{Eu}$ ) and contain pyroxenes (such as Ti-rich augite) and olivine (rich in Mg). Zircons, heavy minerals, are the main host of $\mathrm{Zr}$ in soils and its derived products (i.e. atmospheric dust), are found in coarser particles, and therefore generally settle closer to the source area (Martínez Cortizas et al., 2002; Schuetz, 1989; Taboada et al., 2006). Thus, changes in PC2 of Hani-3 (and PC1 of the second PCA on Hani-1) are considered to be indicative of inputs from locally derived parti-cles (Figure $6 \mathrm{c}$ ). REE along with other lithogenic elements ( $\mathrm{Y}, \mathrm{Al}, \mathrm{Sc}, \mathrm{Th}, \mathrm{Rb}$ ) load on a different $\mathrm{PC}$, namely, $\mathrm{PC} 1$, and this means that they are controlled by a different process. The immobility of REE in peat deposits is now well established (Aubert et al., 2006; Krachler et al., 2003; Kylander et al., 2007, 2013; Pratte et al., 2017; Vanneste et al., 2016). Numerous studies suggest that for the most part, REEs are found in the finer fractions (Gaiero et al., 2004; Gallet et al., 1996, 1998; Weber et al., 1998). The same feature was observed for Th in atmospheric dust, which is enriched in the clay-sized particles (Castillo et al., 2008; McGee et al., 2016; Muhs et al., 2007). This PC is interpreted to represent longerrange atmospheric mineral dust inputs. 


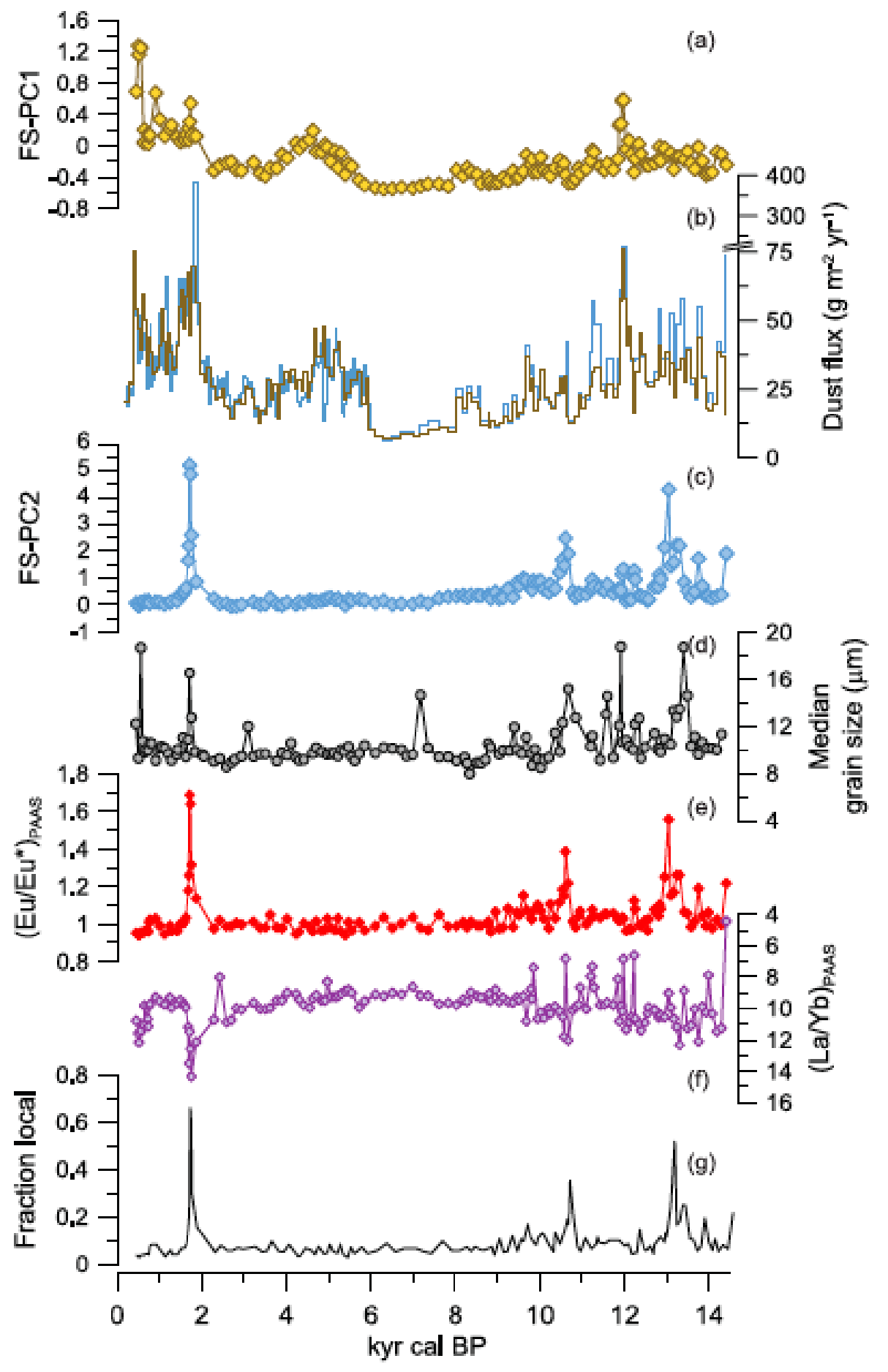

Figure 6. (a) Factor score (FS) of PC1 on Hani-3 core, (b) dust flux based on $\Sigma$ REE (brown) and Ti (blue), (c) factor score of PC2 on Hani-3, (d) median grain-size, (e) Eu/Eu* anomaly normalized to the Post-Archean Australian Shale (Eu/Eu*AAS), (f) (La/Yb) PAAS ratio in the mineral fraction of the Hani peat record and $(\mathrm{g})$ fraction of locally-derived particles based on Eu/Eu* 
(a)

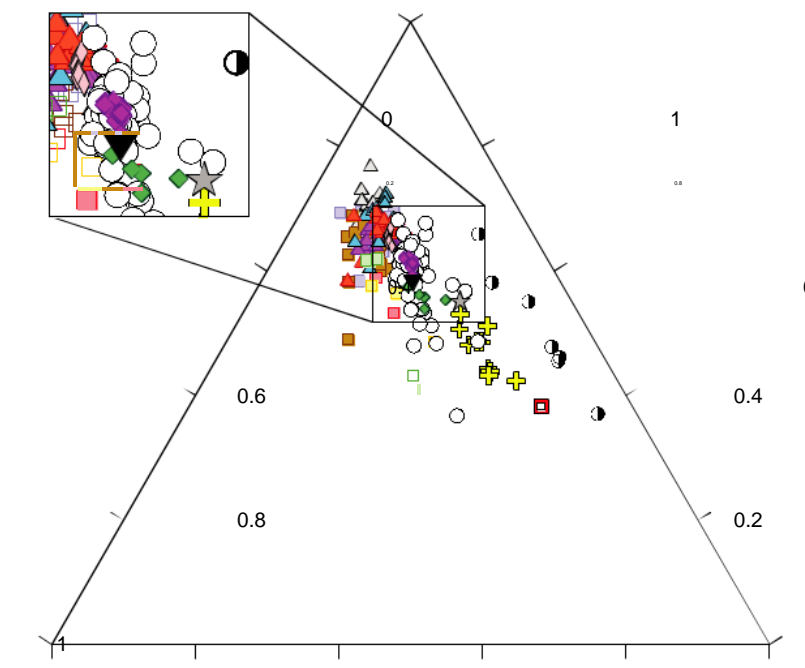

$\mathrm{La}(\mathrm{b})$

Th 0

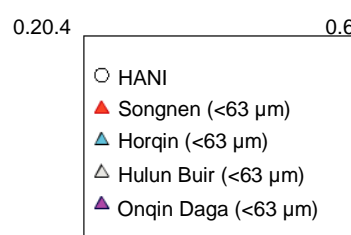

0.6 0.81 Sc Tho

\begin{tabular}{|c|c|c|}
\hline Taklamakan $(<63 \mu \mathrm{m})$ & • Chinese Loess Plateau & \&PAAS \\
\hline Badain Jaran (<75 $\mu \mathrm{m})$ & - Harbin Loess & - Local basalts \\
\hline Ordos ( $<75 \mu \mathrm{m})$ & $\checkmark$ Harbin dust storm & $\oiiint$ Local soils $(<63 \mu \mathrm{m})$ \\
\hline Qaidam $(<75 \mu \mathrm{m})$ & $\nabla$ UCC & Scoria \\
\hline
\end{tabular}

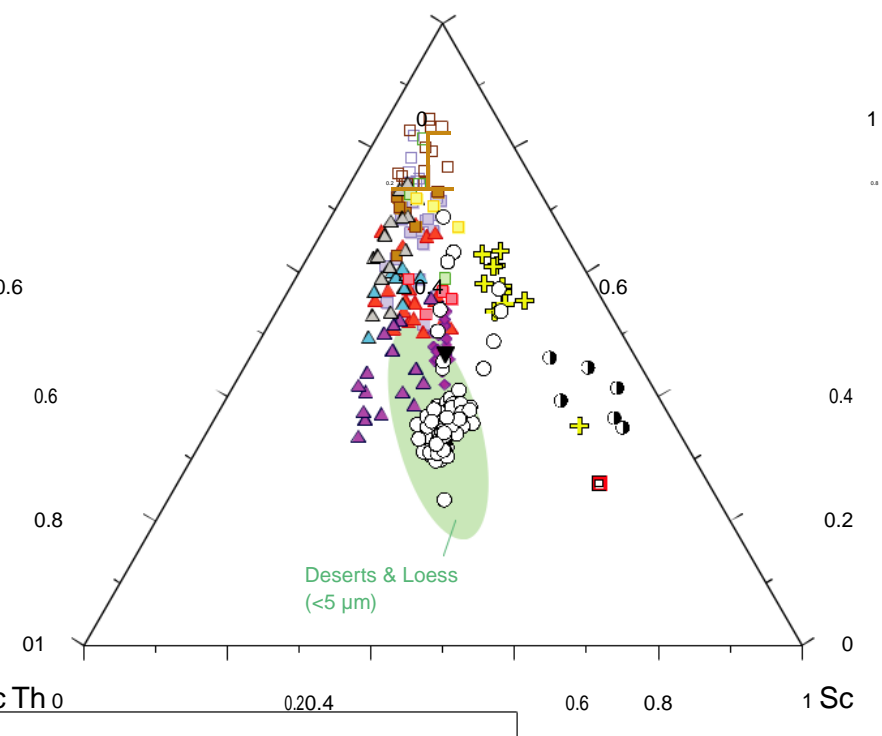

Figure 7. (a) La-Th-Sc and (b) Zr-Th-Sc ternary diagrams based on data from the Hani-3 core. Potential source areas: deserts (squares): Taklamakan (Jiang and Yang, 2019), Qaidam (Zhang et al., 2018), Badain Jaran (Zhang et al., 2018), Gurbantunggut (Zhang et al., 2018) and Ordos (i.e. Mu Us and Hobq; Rao et al., 2011; Zhang et al., 2018); dune fields (triangles): Onqin Daga (Xie et al., 2019; Zhang et al., 2018), Hulun Buir, Horqin and Songnen (Xie et al., 2017); Chinese Loess Plateau (Ferrat et al., 2011); Harbin Loess (Xie et al., 2017) and dust storm (Xie and Chi, 2016). The green area represents the fine fraction of Chinese Deserts, dune fields and loess (Hao et al., 2010; Zhang et al., 2018). Local soils and scoria samples are from this study. Composition of the PAAS and UCC are from Taylor and McLennan (1985); LGVF basalts from Chen et al. (2007).

\section{Preliminary source assessment}

Incompatible elements such as La, Th, Sc and $\mathrm{Zr}$ can be useful tracers for source identification. These can be used to differentiate between sources of felsic (high in La and Th) and mafic (high in Sc) compositions (Olivarez et al., 1991; Taylor and McLennan, 1985). A ternary diagram (Figure 7a) of $\mathrm{La}$, Th and Sc composition of Hani samples reflect a mixing between local mafic sources and allochthonous felsic sources. Based on their close similarity to Hani samples, Chinese deserts and dune fields are considered as a general allochthonous source. However, the specific source cannot be distinguished, which is to be expected given that they are derived from well mixed upper continental crustal materials. This is further evidenced by the mineralogical composition displaying significant amounts of quartz and K-feldspars pointing to a felsic source (Table 2). These minerals tend to be enriched in the coarser fraction $(>2 \mu \mathrm{m}$ ) of dust and loess deposits (Ferrat et al., 2011; Gallet et al., 1996). Although, quartz are generally found in the sand fraction, various processes such as particle impact and salt weathering can produce silt/clay-sized quartz particles (Crouvi et al., 2010; Goudie et al., 1979; Smith et al., 2002). The grain-size distributions in the Hani peat record (average median gain size: $10.5 \pm 1.9 \mu \mathrm{m}$ ) are similar to those of modern dust-fall samples collected near Hani peatland (mean grain size: 12-17 $\mu \mathrm{m}$; Figure 4-1; Li et al., 2017), dust events in the Longgang area in 2002 (median grain size: $6.8 \mu \mathrm{m}$; Figure 4-2; Chu et al., 2009) and Harbin City in 2011 (mean grain-size: $12.1 \mu \mathrm{m}$; Xie and Chi, 2016) as well as sediments from lake Sihailongwan (Figure 4-3; Chu et al., 2009). While the use of grain size alone to decipher the source of mineral particles is limited by several factors (methodological, similar distribution produced by different processes), it provides further indications for a mainly allochthonous origin of the mineral particles when combined with geochemistry and mineralogy. Additional evidence that the mineral particles deposited in Hani are from far-travelled desert dust is provided by the relative abundance of $\mathrm{Zr}$-Sc-Th (Figure 7b). The composition of Hani samples is close to the compositional field of the fine fraction $(<5 \mu \mathrm{m})$ of deserts, dune fields and loess of China. Concentrations of $\mathrm{Zr}$ vary with particle size, that is, finer fractions of dust have lower contents than do coarser ones (Schuetz, 1989).

The La-Th-Sc ternary diagram also shows that some samples display a more mafic composition closer to local soils, scoria and basalts (Figure 7a). This suggests that local source(s) also contribute to the mineral input to Hani peatland. This is further supported by the occurrence of positive peaks in Eu anomaly and the record of PC2 (Figure 6c and e). Alkali and plagioclase feldspars typically have higher Eu contents but lower REE concentrations (Taylor and McLennan, 1985). The peak in Eu anomaly around $1700 \mathrm{yr}$ cal. BP is the most positive (1.68) and displays the highest content in plagioclase feldspars of the record (Table 2). Although top-soils of the region have encompassed important quantities of material from distal dust deposition (Zhao et al., 1997), they inherited the REE signature of the local basaltic rocks and typically show positive Eu anomalies (normalized to Post-Archean Australian Shales (PAAS): Eu/Eu*PAAS = 1.29-1.56; this study and Schettler et al., 2006a). Scoria fall and tephra deposits, displaying positive Eu anomalies, are also present in the vicinity of the Hani peatland and likely con-tributed to the mineral supply (Liu et al., 2009). Samples older than $9.5 \mathrm{kyr}$ displaying a positive Eu anomaly generally also show a HREE enrichment $\left((\mathrm{La} / \mathrm{Yb})_{\text {PAAS; }}\right.$ Figure 6f) and are often characterized by grain-size distributions displaying a mode in the $>100 \mu \mathrm{m}$ fraction (Cluster 3; Figure 4c). Particles larger than $100 \mu \mathrm{m}$ are rarely transported by suspension especially over distances such as those necessary $(>600 \mathrm{~m})$ to reach the core locations and given the heterogeneity and irregularity of the peatland vegetation. Such particles are generally transported by saltation and runoff (Tsoar and Pye, 1987). This is evidenced by the finer main mode and less frequent coarse particles of our core when compared with another core collected at the margin of the Hani peatland (Li et al., 2017). All these evidence points towards more frequent influxes of locally derived minerals during the late Pleistocene and early Holocene. 
A binary mixing equation, using an average $\mathrm{Eu}$ anomaly from local volcanic sources $\left(\mathrm{Eu} / \mathrm{Eu}^{*}=1.93\right)$ and from the $<75 \mu \mathrm{m}$ fraction of deserts and dune fields $\left(E u / E^{*}=0.89\right)$, was used to obtain a first estimate of local source contribution to the Hani dust record (Figure $6 \mathrm{~g}$ ). Local sources account for less than 10\% of the mineral input in most of the record, apart for a peak around $1.7 \mathrm{kyr}$ cal. BP $(66 \%)$ and between 9.7 and $10.7 \mathrm{kyr}(11-36 \%)$ and $12.8-13.5 \mathrm{kyr}$ cal. BP (10-52\%). A more extensive investigation of the sources using other REE ratios and more particularly stable isotopes ( $\mathrm{Nd}, \mathrm{Sr}, \mathrm{Pb})$ would be needed to discriminate more precisely between local and allochthonous sources, but more importantly those allochthonous between themselves, that is, the different deserts and dune fields.

\section{Palaeoclimatic implications}

Comparison with other climatic records in northern and NE China. As the mineral particles deposited in Hani peatland are mainly of allochthonous origin and derived from the deserts and dune fields of northern China (Figure 7), the Hani record is compared with climatic records from these regions. Dust mobilization and transport is in general directly proportional to wind velocity and the ratio of precipitation/potential evapotranspiration or aridity (impacting on soil moisture and vegetation cover) in the source region (Lancaster, 1988; Tsoar and Pye, 1987), hence our record is compared with records of aeolian intensity and moisture/aridity.

\section{Comparison with records of aeolian activity.}

The Hani profile is compared with various aeolian records from northern and NE China, including lake records from arid/semi-arid China and downwind of dust source areas, late Pleistocene and Holocene loess and dune sand/palaeosol records in dust source regions. Most of these records are consistent with ours, displaying greater aeolian activity during the late Pleistocene and late Holocene than during the early and especially the middle Holocene. Dust deposition during the late Pleistocene is relatively high compared with the early and middle Holocene (Figure $8 \mathrm{~m}$ ), a feature also found in the maar lake Sihailongwan, a geochemical record of the input of allochthonous siliciclastic material, located $12 \mathrm{~km}$ to the north-east of Hani (Figure 8k; Schettler et al., 2006a). A clear peak in dust ARs (12.2-11.8 kyr cal. BP), displaying an allochthonous felsic composition, is observed during the Younger Dryas (YD; Figure 8m). This increase in dust deposition is also present in the Sihailongwan maar record. While late-Pleistocene records of aeolian activity other than loess are limited, intensified aeolian activity, based on grain-size fractions, was recorded in lake sediments of arid Central Asia and Lake Qinghai during the YD (An et al., 2011, 2012). Enhanced aeolian activity was also inferred from dune records along the southern margin of the Chi-nese desert of northern China during late Pleistocene and the YD (Lu et al., 2013; Stauch, 2019).

Terrestrial records (lakes and peatlands) of aeolian activity from potential dust source regions and downwind areas display a similar pattern as Hani dust deposition during the Holocene (Figure 8i-k). The aeolian records of lake Xiarinur (Figure 8i; proportion of 15-63 and >150 $\mu \mathrm{m}$ fractions; Xu et al., 2018), in the Onqin Daga dune fields, and lake Tuolekule (mean and $>63 \mu \mathrm{m}$ fraction; An et al., 2011), in NW China, based on the particle grain size, both show that aeolian activity was relatively low in the early Holocene, reached a minimum in the middle Holocene, and increased after $6.0 \mathrm{kyr}$ cal. BP. Downwind of the dust source regions, a peat bog record of mineral dust deposition, based on REE and Pb isotopic composition, also supports an increase in aeolian activity during the late Holocene on the eastern Qinghai-Tibetan Plateau (Ferrat et al., 2012a, 2012b). In NE China, lake Sihailongwan shows a gradually decreasing trend in aeolian dust deposition from the early to the middle Holocene (Figure 8k; Schettler et al., 2006a, 2006b; Zhu et al., 2013), while a minima in aeolian activity is suggested during the middle Holocene when compared with the late Holocene by the aeolian dust fraction $(<37$ $\mu \mathrm{m}$; Figure 8I) in Gushantun peat record (Li et al., 2017) and an aeolian quartz flux reconstruction on Cheju Island, in South Korea (Lim et al., 2015).

Records of aeolian sands, implying sand mobility (i.e. increased aeolian activity or dune expansion/build-up), and palaeosols, indicating lower aeolian activity and increased vegetation cover, from dune fields have been extensively studied in the Chinese drylands (Li et al., 2002; Lu et al., 2013; Mason et al., 2009; Sun et al., 2006). A compilation of OSL ages of aeolian sands/palaeosols in over 150 profiles covering the entire Asian dust source regions (see deserts and dune fields in Figure 1a) consistently suggests increased aeolian activity (more ages from aeolian sands) during the late Holocene (last 5 kyr) compared with the early and middle Holocene (more ages from palaeosols; 5-12 kyr; Xu et al., 2018 and references therein). This feature is also apparent across loess/ palaeosols records from the Chinese Loess Plateau, where the highest numbers of OSL ages from aeolian sands were related to the period after $3.4 \mathrm{kyr}$ (Figure 8j), indicating increased aeolian activity in Chinese dust source regions (Porter, 2001; Wang et al., 2014). This is also consistent with a southward migration of the boundary of the deserts and dune fields of China from the middle to the late Holocene (Lu et al., 2013).

\section{Comparison with records of humidity/aridity.}

The Hani dust record generally displays higher dust deposition during drier periods reconstructed in terrestrial records from northern and NE China (Figure 8d-h). Several climatic records (temperature and humid-ity/precipitations) reconstruct drier or colder conditions during the YD in northern and NE China (Fan et al., 2018; Goldsmith et al., 2017; Stebich et al., 2009; Wang et al., 1994; Wu et al., 2016; Zheng et al., 2017). A reconstruction of effective moisture across the Chinese drylands, combining aeolian sand sequences and vegetation reconstructions, suggests a more arid climate dur-ing the late Pleistocene followed by gradually more humid condi-tions throughout the early Holocene (Li et al., 2014). Various records across the Chinese dust source regions sug-gest the climate was relatively humid during the early Holocene with a trend towards even more humid conditions into the middle Holocene which became significantly drier during the late Holo-cene (Chen et al., 2015; Goldsmith et al., 2017; Shen et al., 2005; Wen et al., 2010; Xiao et al., 2004; Xu et al., 2018; Zhao et al., 2009). These records include (1) a moisture index synthesized from fossil-pollen records (30) across arid and semi-arid China (Figure 8d; Zhao et al., 2009); (2) a lake-level reconstruction from the closed lake Dali in Inner Mongolia (Figure 8e; Goldsmith et al., 2017); (3) a pollen-based reconstruction of annual precipi-tations from lake Hulun, NE China (Figure 8f; Wen et al., 2010). However, some records from NE China suggest that conditions were drier during the early Holocene than the late Holocene (Chen et al., 2008, 2019; Stebich et al., 2015; Zheng et al., 2018) more in agreement with observations in arid Central Asia (Chen et al., 2016; Wang and Feng, 2013). Nevertheless, the same pat-tern of increasing humidity towards the middle Holocene and dry-ing during the late Holocene is present in many of these records (Figure $8 \mathrm{~h}$ ). All these evidence consistently support that the cli-mate gradually got more humid from the early to the middle Holocene and subsequently became drier over the late Holocene across the Chinese dust source regions. 


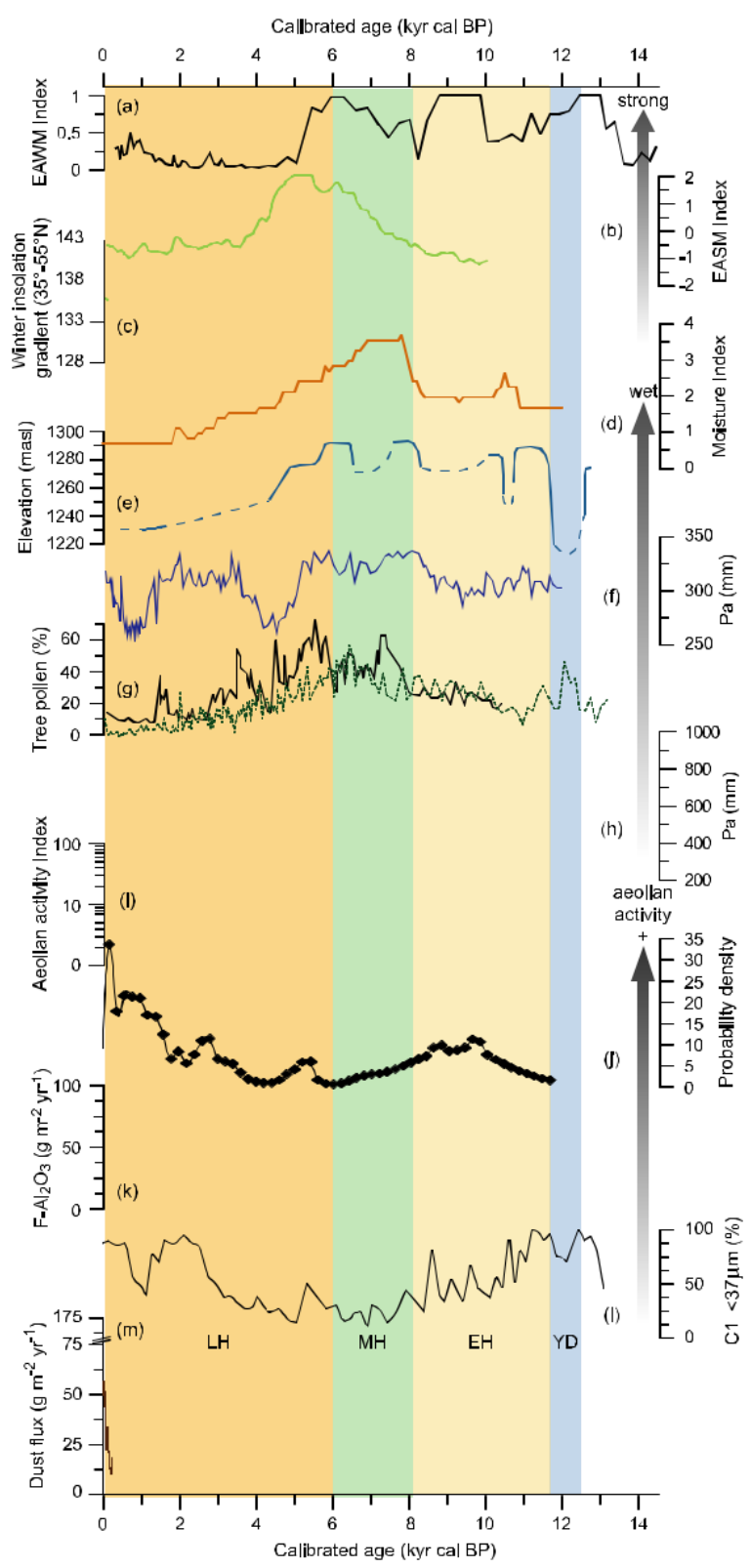

Figure 8. (a) Diatom-based EAWM index from Wang et al. (2012); (b)pollen-based EASM index from monsoonal eastern China (Wang et al., 2010); (c) strength of the Westerlies represented by the winter insolation gradient between $35^{\circ} \mathrm{N}$ and $55^{\circ} \mathrm{N}$ (Chen et al., 2016); (d) moisture index synthesized from pollen-based records in eastern Inner Mongolia (orange line) and arid/semi-arid China (black line; Zhao et al., 2009); (e) lake level of Lake Dali, Inner Mongolia (Goldsmith et al., 2017); (f) pollen-based annual precipitation $\left(P_{a}\right)$ reconstruction from lake Hulun, Inner Mongolia (Wen et al., 2010); (g) percentage of tree pollens from lakes Dahai, Inner Mongolia (black line; Xiao et al., 2004) and Qinghai, Tibetan Plateau (dashed green line; (Shen et al., 2005); (h) pollen-based annual precipitation reconstruction from lake Sihailongwan (Stebich et al., 2015); (i) aeolian activity index from lake Xiarinur (Xu et al., 2018); (j) probability density of aeolian sand dates on the Chinese Loess Plateau (Wang et al., 2014); (k) siliclastic influx $\left(\mathrm{F}_{-} \mathrm{Al}_{2} \mathrm{O}_{3}\right)$ to lake Sihailongwan, NE China (Schettler et al., 2006a); (I) grain-size component $(<37 \mu \mathrm{m})$ in Gushantun (green curve) peatland (Li et al., 2017); and (m) Hani peatland non-local dust flux from allochthonous sources (this study).LH: late Holocene; $\mathrm{MH}$ : middle Holocene; EH: early Holocene; YD: Younger Dryas. 
Over the last $6.0 \mathrm{kyr}$ cal. BP, three peaks in dust deposition centred around 5.0, 1.5 and $0.5 \mathrm{kyr}$ cal. BP are found in the Hani record (Figure $8 \mathrm{~m}$ ). While, the earlier peak is not as ubiquitous as those discussed above, a number of records, mostly in the eastern part of the Chinese dust areas, suggest a shift in climate. The OSL dating of sand/palaeosol profiles from deserts of northern China (Mu Us, Hobq, Horqin and Hulun Buir) displays a transition from palaeosol to aeolian sands between 5.7 and 4.4 kyr BP, suggesting a rapid drying ( $\mathrm{Li}$ et al., 2007). In addition, lake-level and lacus-trine pollen records display a decline in precipitation at 5.3-4.5 kyr cal. BP in Inner Mongolia (Figure 8d-f; Goldsmith et al., 2017; Wen et al., 2010). The two following peaks broadly fit in the general late Holocene decrease in effective moisture that is consistently reported across arid and semi-arid China (Shen et al., 2005; Wen et al., 2010; Xiao et al., 2004; Xu et al., 2018).

To summarize, a large proportion of the records located in the Chinese dust areas, their downwind regions and NE China are consistent with the Hani peatland dust deposition record indicat-ing drier conditions and high aeolian activity during the late Holo-cene, which suggests a relationship between aeolian activity, aridity/effective moisture and dust deposition in the region. How-ever, discrepancies with some records in NE China and arid Cen-tral Asia suggest some spatial heterogeneity.

\section{Potential controlling factors.}

Asian dust emission and transport is mainly controlled by the Westerlies and the EAWM through the forcing of the SH (Sun et al., 2001). Modern dust storms in north-ern China mainly occur in spring (March, April, May) during the breakdown of the $\mathrm{SH}$ creating cold fronts (Roe, 2009). However, the similarity between the different potential source areas (Figure 7a) currently prevents the identification of a precise source and, by extension, which system controls dust supply to Hani peatland. Furthermore, comparing our dust deposition record with the dia-tom-based index of the EAWM from Huguang Maar lake (Figure 8a; Wang et al., 2012), the late Holocene (middle Holocene) high (low) dust flux occurs during a period of low (high) EAWM inten-sity, which suggest that the Hani record is not the direct result of the variations in EAWM.

The similarity of the Hani record with records of aeolian activ-ity and aridity/humidity from arid and semi-arid China (Figure 8), along with the allochthonous felsic geochemical composition of the mineral particles (Figure 7), implies that the dust supply to Hani peatland is controlled by the climatic and environmental changes occurring in the dust source regions of China. Changes in aridity have widely been invoked to explain increased dust emis-sions (Biscaye et al., 1997; Harrison et al., 2001; Rea and Leinen, 1988). Nevertheless, as discussed by Marx et al. (2018), major dust sources, such as the deserts and dune fields across northern China, are located in already arid environments, in which mois-ture levels rarely inhibit dust emission. Other factors, such as veg-etation cover, sediment recharge and wind intensity can play an important role on dust availability. However, some of these fac-tors are partially controlled by moisture/precipitation levels such as vegetation cover and sediment recharge.

Modern observations on dune mobility in northern dune fields suggest that changes in wind strength (aeolian intensity) alone has limited effect on the mobilization/stabilization of dunes and other factors need to be involved (Mason et al., 2008). In arid and semiarid regions, vegetation is very sensitive to effective moisture (the balance between precipitations and potential evapotranspiration; Liu et al., 2005). The relationship is evidenced by a similar trend of the vegetation cover reconstruction with those of humidity/aridity. Deserts and dune field areas were reduced during the middle Holo-cene (Dallmeyer et al., 2015; Lu et al., 2013), the eastern dune fields (Mu Us, Onqin Daga, Hulun Buir and Horqin) being nearly entirely covered by vegetation (Lu et al., 2013; Yang et al., 2013).

The palaeoclimatic and palaeoenvironmental changes observed in the dust source regions of China are consistent with the Holocene variability of the EASM and suggest that precipitations in arid and semi-arid China was controlled by this mechanism (Wang et al., 2010). Most of the deserts and dune fields are located in the marginal zone of the EASM where it plays a significant role in the hydrological balance and effective moisture, especially in the east-ern dune field regions (Lu et al., 2005; Winkler and Wang, 1993). The EASM records from northern China monsoon frontal area, including a EASM index from a meta-analysis of moisture/tem-perature records (92) across monsoonal China (Figure 8b; Wang et al., 2010), tree pollen from Dahai and Qinghai lakes (Figure 8g; Shen et al., 2005; Xiao et al., 2004), reconstructed precipitations from Lake Gonghai (Chen et al., 2015), lake levels from lake Dali (Figure 8e; Goldsmith et al., 2017) consistently suggest that the strength of the EASM gradually increased during early Holocene, reaching its maximum intensity and northward extent during the middle Holocene (6-7 kyr cal. BP) and subsequently gradually decreased from 4-6 kyr cal. BP with a southward retreat (Dong et al., 2018; Wang et al., 2010, 2014).

The entire desert belt experienced wetter conditions between 8 and 4 kyr depending on the regions (Yang et al., 2011). It is rea-sonable to think that an enhanced intensity and a further northern limit of the EASM during the middle Holocene could have resulted in a sediment recharge along the margin of the Chinese drylands affected by the EASM. The subsequent weakening of the EASM and corresponding increased aridity during the late Holo-cene would result in greater sediment availability and potentially greater atmospheric dust loads.

The case of the YD is of particular interest. While a dust peak is observed in the Hani record, it is not as prominent as those observed during the late Holocene and its time span is short lived (11.8-12.2 kyr cal. BP; Figure 8m). The EASM records consistently display a weakening during the YD (An et al., 2012; Chen et al., 2015; Dykoski et al., 2005). Assuming that the relationship between the Hani dust record and the climatic/environmental changes in the Chinese dust source regions still holds for the YD, this would suggest that the region was also drier during the YD. However, there are discrepancies among the humidity/precipita-tion records during the YD (Goldsmith et al., 2017; Li et al., 2017; Schettler et al., 2006b; Stebich et al., 2015; Zhou et al., 2010), so it still unclear what controlled humidity during this period. Some of the discrepancies might be ascribed to the fact that some of these records are based on single proxies which encompass cli-matic signal differently from one to another. The lower dust flux might partially be explained by the presence of permafrost in some regions and longer frost seasons, inhibiting dust entrain-ment (Jin et al., 2000; Parplies et al., 2008).

To summarize, dust deposition in Hani display a close resem-blance to the aridity/humidity and aeolian intensity records from the Chinese dust source regions and their downwind areas. An inverse relationship is observed where minima (maxima) in dust deposition correspond to maxima (minima) in effective moisture/ precipitations and vegetation cover in the various proxy records. The similarity of this pattern with the known Holocene variability of the EASM suggests that climatic changes in the Chinese dry-lands are controlled by this mechanism. Hence, the climatic con-ditions created by the weakening of the EASM during the late Holocene created conditions favourable for the mobilization of dust by the EAWM or the Westerlies (Figure 8), which was depos-ited in Hani peatland downwind.

Superimposed on these climatic mechanisms is the potential influence of human activities, especially during the late Holocene. There is increasing evidence of human occupation and activities in Chinese drylands as early as around 7.0 kyr cal. BP, but more sig-nificantly after $2.0 \mathrm{kyr}$ cal. BP (Dodson et al., 2009; Schültz and Lehmkuhl, 2009; Zhuo et al., 2013). Further research is needed 
to assess the significance of anthropogenic activities on dust emis-sions in northern China's drylands since it is clear that this is a factor that impacted the environment during the late Holocene (Schültz and Lehmkuhl, 2009; Zhu et al., 1989; Zhuo et al., 2013). 


\section{Conclusion}

Elemental concentrations, combined with mineralogy and particle grain size, in a $9.3 \mathrm{~m}$ long peat section from the Hani peatland, from the Changbai Mountains (NE China), allowed for the recon-struction of variations in dust deposition over the late Pleistocene and the Holocene. The dust record displays a sharp increase in dust deposition during the late Holocene in comparison to the rest of the Holocene, in line with climatic records from the Chinese dust source regions and their downwind areas, which generally record increased aridity and aeolian activity during the same period. These changes in the dust source regions are likely to have been modulated by the variations in the EASM, which is the prin-cipal mechanism controlling climate in the region. Combined together, these changes promoted a remobilization of dust sources increasing the amount of material available for transport by the EAWM and the Westerlies. Human activities might also have played a role in the increased dust emissions during the late Holocene, but further research is needed to assess the extent of those impacts at a regional level.

\section{Acknowledgements}

We are grateful to Rongqin Liu for lab assistance at NIGLAS. The ICP-MS service of OMP (A Lanzanova, C Duqenoy) as well M-J Tavella (EcoLab) are acknowledged for assistance with sample preparation and Q-ICP-MS measurements. We are thankful to two anonymous reviewers for their constructive comments on a previous version of the manuscript.

\section{Funding}

The author(s) disclosed receipt of the following financial sup-port for the research, authorship and/or publication of this article: This research was supported by the NSFC-CNRS Joint Research Project (grant no. 41611130163) to KB and FDV, the Chinese Academy of Sciences President's International Fellowship Initia-tive (PIFI; grant no. 2017PC0078) to SP, and the National Nature Science Foundation of China (NSFC; grant no. 41971113) to KB. 


\section{References}

An C-B, Zhao J, Tao S et al. (2011) Dust recorded by lacustrine sediments from arid Central Asia since $\sim 15$ cal ka BP and its implication for atmospheric circulation. Quater-nary Research 75: 566-573.

An Z, Colman SM, Zhou WJ et al. (2012) Interplay between the Westerlies and Asian monsoon recorded in Lake Qinghai sed-iments since $32 \mathrm{ka}$. Scientific Reports 2: 619-625.

An Z, Liu T, Lu Y et al. (1990) The long-term paleomonsoon variation recorded by the loess-paleosol sequence in Central China. Quaternary International 7-8: 91-95.

Aubert D, Le Roux G, Krachler M et al. (2006) Origin and fluxes of atmospheric REE entering an ombrotrophic peat bog in Black Forest (SW Germany): Evidence from snow, lichens and mosses. Geochimica et Cosmochimica Acta 70: 2815-2826.

Bao K, Xia W, Lu X et al. (2010) Recent atmospheric lead deposi-tion recorded in an ombrotrophic peat bog of Great Hinggan Mountains, Northeast China, from 210Pb and 137Cs dating. Journal of Environmental Radioactivity 101: 773-779.

Bao K, Xing W, Yu X et al. (2012) Recent atmospheric dust depo-sition in an ombrotrophic peat bog in Great Hinggan Mountain, Northeast China. Science of the Total Environment 431: 33-45.

Becker JJ, Sandwell DT, Smith WHF et al. (2009) Global bathymetry and elevation data at 30 arc seconds resolution: SRTM30_PLUS. Marine Geodesy 32: 355-371.

Biscaye PE, Grousset FE, Revel M et al. (1997) Asian provenance of glacial dust (stage 2) in the Greenland Ice Sheet Project 2 Ice Core, Summit, Greenland. Journal of Geophysical Research: Oceans 102: 26765-26781.

Blaauw M and Christen JA (2011) Flexible paleoclimate age-depth models using an autoregressive gamma process. Bayesian Analysis 6: 457-474.

Bu Z, Chen X, Rydin H et al. (2013) Performance of four mosses in a reciprocal transplant experiment: Implications for peatland succession in NE China. Journal of Bryology 35: 220-227.

Bureau of Geology and Mineral Resource of Jilin Province (1988) Regional Geology of Jilin Province. Beijing: Geological Press, pp. 698. (in Chinese).

Castillo S, Moreno T, Querol X et al. (2008) Trace element varia-tion in size-fractionated African desert dusts. Journal of Arid Environments 72: 1034-1045.

Chambers FM, Beilman DW and Yu ZC (2011) Methods for determining peat humification and for quantifying peat bulk density, organic matter and carbon content for palaeostudies of climate and peatland carbon dynamics. Mires and Peat 7: 110.

Chen FH, Chen J, Huang W et al. (2019) Westerlies Asia and monsoonal Asia: Spatiotemporal differences in climate change and possible mechanisms on decadal to sub-orbital timescales. Earth-Science Reviews 192: 337-354.

Chen FH, Jia J, Chen J et al. (2016) A persistent Holocene wetting trend in arid central Asia, with wettest conditions in the late Holocene, revealed by multi-proxy analyses of loess-paleosol sequences in Xinjiang, China. Quaternary Science Reviews 146: 134-146.

Chen $\mathrm{FH}, \mathrm{Xu} \mathrm{QH}$, Chen JH et al. (2015) East Asian summer mon-soon precipitation variability since the last deglaciation. Sci-entific Reports 5: 11186.

Chen FH, Yu Z, Yang M et al. (2008) Holocene moisture evo-lution in arid central Asia and its out-of-phase relationship with Asian monsoon history. Quaternary Science Reviews 27: 351-364.

Chen Y, Zhang Y, Graham D et al. (2007) Geochemistry of Ceno-zoic basalts and mantle xenoliths in Northeast China. Lithos 96: 108-126.

Chu G, Sun Q, Zhaoyan G et al. (2009) Dust records from varved lacustrine sediments of two neighboring lakes in northeastern China over the last 1400 years. Quaternary International 194: 108-118.

Commission for the Compilation of the Geological Map of China (1990) Geological Map of China (1: 5 000 000). Geological House, Beijing. (in Chinese)

Crouvi O, Amit R, Enzel Y et al. (2010) Active sand seas and the formation of desert loess. Quaternary Science Reviews 29: 2087-2098.

Dallmeyer A, Herzschuh U, Claussen M et al. (2015) Vegetation, climate, man: Holocene variability in monsoonal Central Asia. In: Schulz M and Paul A (eds) Integrated Analysis of Interglacial Climate Dynamics (INTERDYNAMIC). Cham: Springer International Publishing, pp. 97-102.

De Jong R, Schoning K and Björck S (2007) Increased aeolian activity during humidity shifts as recorded in a raised bog in south-west Sweden during the past 1700 years. Climate of the Past 3: 411-422.

De Vleeschouwer F, Ferrat M, McGowan H et al. (2014a) Extract-ing paleodust information from peat geochemistry. PAGES Magazine 22: 88-89. 
De Vleeschouwer F, Vanneste H, Mauquoy D et al. (2014b) Emis-sions from pre-Hispanic metallurgy in the South American atmosphere. PLOS ONE 9: e111315.

Delmonte B, Baroni C, Andersson PS et al. (2010) Aeolian dust in the Talos Dome ice core (East Antarctica, Pacific/Ross Sea sector): Victoria Land versus remote sources over the last two climate cycles. Journal of Quaternary Science 25: 13271337. deMenocal P, Ortiz J, Guilderson T et al. (2000) Abrupt onset and termination of the African Humid Period: Rapid climate responses to gradual insolation forcing. Quaternary Science Reviews 19: 347-361.

Dodson J, Li X, Ji M et al. (2009) Early bronze in two Holo-cene archaeological sites in Gansu, NW China. Quaternary Research 72: 309-314.

Dong J, Shen C-C, Kong X et al. (2018) Rapid retreat of the East Asian summer monsoon in the middle Holocene and a millen-nial weak monsoon interval at 9 ka in northern China. Journal of Asian Earth Sciences 151: 31-39.

Dykoski CA, Lawrence Edwards R, Cheng $\mathrm{H}$ et al. (2005) A high-resolution, absolute-dated Holocene and deglacial Asian monsoon record from Dongge cave, China. Earth and Plan-etary Science Letters 233: 71-86.

Eriksson L, Johansson EN, Kettapeh-Wold S et al. (1999) Intro-duction to Multi- and Megavariate Data Analysis Using Projection Methods (PCA \& PLS). Umeå: Umetrics.

Fábregas Valcarce R, Martínez Cortizas A, Blanco Chao R et al. (2003) Environmental change and social dynamics in the sec-ond-third millennium BC in NW Iberia. Journal of Archaeo-logical Science 30: 859-871.

Fan J, Xiao J, Wen R et al. (2018) The manifestation of the Younger Dryas event in the East Asian summer monsoon margin: New evidence from carbonate geochemistry of the Dali Lake sediments in northern China. The Holocene 28: 10821092.

Ferrat M, Weiss DJ, Dong S et al. (2012a) Lead atmospheric deposition rates and isotopic trends in Asian dust during the last $9.5 \mathrm{kyr}$ recorded in an ombrotrophic peat bog on the east-ern Qinghai-Tibetan Plateau. Geochimica et Cosmochimica Acta 82: 4-22.

Ferrat M, Weiss DJ, Spiro B et al. (2012b) The inorganic geo-chemistry of a peat deposit on the eastern Qinghai-Tibetan Plateau and insights into changing atmospheric circulation in central Asia during the Holocene. Geochimica et Cosmochimica Acta 91: 7-31.

Ferrat M, Weiss DJ, Strekopytov S et al. (2011) Improved prov-enance tracing of Asian dust sources using rare earth elements and selected trace elements for palaeomonsoon studies on the eastern Tibetan Plateau. Geochimica et Cosmochimica Acta 75: 6374-6399.

Filipsson HL, Romero OE, Stuut J-BW et al. (2011) Relationships between primary productivity and bottom-water oxygenation off northwest Africa during the last deglaciation. Journal of Quaternary Science 26: 448-456.

Gaiero DM, Depetris PJ, Probst J-L et al. (2004) The signature of river- and wind-borne materials exported from Patagonia to the southern latitudes: A view from REEs and implications for paleoclimatic interpretations. Earth and Planetary Sci-ence Letters 219: 357-376.

Gallet S and Jahn B-m Torii M (1996) Geochemical character-ization of the Luochuan loess-paleosol sequence, China, and paleoclimatic implications. Chemical Geology 133: 67-88.

Gallet S, Jahn B-m, Van Vliet Lanoe B et al. (1998) Loess geo-chemistry and its implications for particle origin and composition of the upper continental crust. Earth and Planetary Science Letters 156: 157-172.

Ginoux P, Prospero JM, Torres $\mathrm{O}$ et al. (2004) Long-term simu-lation of global dust distribution with the GOCART model: Correlation with North Atlantic oscillation. Environmental Modelling \& Software 19(2): 113-128.

Goldsmith Y, Broecker WS, Xu H et al. (2017) Northward extent of East Asian monsoon covaries with intensity on orbital and millennial timescales. Proceedings of the National Academy of Sciences of the United States of America 114: 1817-1821.

Goudie AS, Cooke RU and Doornkamp JC (1979) The formation of silt from quartz dune sand by salt-weathering processes in deserts. Journal of Arid Environments 2: 105-112.

Gu N, Jiang W, Wang L et al. (2015) Rainfall thresholds for the precipitation of carbonate and evaporite minerals in modern lakes in northern China. Geophysical Research Letters 42: 5895-5901.

Hao Q, Guo Z, Qiao Y et al. (2010) Geochemical evidence for the provenance of middle Pleistocene loess deposits in southern China. Quaternary Science Reviews 29: 3317-3326.

Harrison SP, Kohfeld KE, Roelandt $C$ et al. (2001) The role of dust in climate changes today, at the last glacial maximum and in the future. Earth-Science Reviews 54: 43-80.

Jiang $Q$ and Yang X (2019) Sedimentological and geochemical composition of aeolian sediments in the Taklamakan desert: implications for provenance and sediment supply mecha-nisms. Journal of Geophysical Research: Earth Surface 124: 12171237. 
Krachler M, Mohl C, Emons H et al. (2003) Two thousand years of atmospheric rare earth element (REE) deposition as revealed by an ombrotrophic peat bog profile, Jura Mountains, Swit-zerland. Journal of Environmental Monitoring 5: 111-121.

Kylander ME, Bindler R, Martínez Cortizas A et al. (2013) A novel geochemical approach to paleorecords of dust depo-sition and effective humidity: 8500 years of peat accumula-tion at Store Mosse (the 'Great Bog'). Quaternary Science Reviews 69: 69-82.

Kylander ME, Martinez-Cortizas A, Bindler R, et al. (2016) Poten-tials and problems of building detailed dust records using peat archives: an example from Store Mosse (the "Great Bog"), Sweden. Geochimica et Cosmochimica Acta 190: 156-174.

Kylander ME, Muller J, Wüst RAJ et al. (2007) Rare earth ele-ment and Pb isotope variations in a 52 kyr peat core from Lynch's Crater (NE Queensland, Australia): Proxy develop-ment and application to paleoclimate in the Southern Hemisphere. Geochimica et Cosmochimica Acta 71: 942-960.

Lambert F, Delmonte B, Petit JR et al. (2008) Dust-climate cou-plings over the past 800,000 years from the EPICA Dome C ice core. Nature 452: 616-619.

Lancaster N (1988) Development of linear dunes in the south-western Kalahari, Southern-Africa. Journal of Arid Environments 14: 233-244.

Li N, Chambers FM, Yang J et al. (2017) Records of East Asian monsoon activities in Northeastern China since 15.6 ka, based on grain size analysis of peaty sediments in the Changbai Mountains. Quaternary International 447: 158-169.

Li Q, Wu H, Yu Y et al. (2014) Reconstructed moisture evolution of the deserts in northern China since the Last Glacial Maxi-mum and its implications for the East Asian Summer Mon-soon. Global and Planetary Change 121: 101-112.

Li S-H, Chen Y-Y, Li B et al. (2007) OSL dating of sediments from deserts in northern China. Quaternary Geochronology 2: 23-28.

Li S-H, Sun J-M and Zhao H (2002) Optical dating of dune sands in the northeastern deserts of China. Palaeogeography, Palaeoclimatology, Palaeoecology 181: 419-429.

Lim J, Matsumoto E and Kitagawa H (2015) Eolian quartz flux variations in Cheju Island, Korea, during the last 6500 yr and a possible Sun-monsoon linkage. Quaternary Research 6: 12-20.

Liu J, Chu G, Han J et al. (2009) Volcanic eruptions in the Long-gang volcanic field, northeastern China, during the past 15,000 years. Journal of Asian Earth Sciences 34: 645-654.

Liu LY, Skidmore E, Hasi E et al. (2005) Dune sand transport as influenced by wind directions, speed and frequencies in the Ordos Plateau, China. Geomorphology 67: 283-297.

Lu HY, Miao XD, Zhou YL et al. (2005) Late Quaternary aeo-lian activity in the Mu Us and Otindag dune fields (North China) and lagged response to insolation forcing. Geophysi-cal Research Letters 32: L21716.

Lu HY, Yi SW, Xu ZW et al. (2013) Chinese deserts and sand fields in Last Glacial Maximum and Holocene Optimum. Chinese Science Bulletin 58: 2775-2783.

McGee D, Winckler G, Borunda A et al. (2016) Tracking eolian dust with helium and thorium: Impacts of grain size and prov-enance. Geochimica et Cosmochimica Acta 175: 47-67.

Maher BA, Prospero JM, Mackie D et al. (2010) Global con-nections between aeolian dust, climate and ocean biogeochemistry at the present day and at the last glacial maximum. Earth-Science Reviews 99: 61-97.

Martínez Cortizas A, García-Rodeja E, Pontevedra Pombal X et al. (2002) Atmospheric Pb deposition in Spain during the last 4600 years recorded by two ombrotrophic peat bogs and implications for the use of peat as archive. Science of the Total Environment 292: 33-44.

Marx SK, Kamber BS, McGowan HA et al. (2018) Palaeo-dust records: A window to understanding past environments. Global and Planetary Change 165: 13-43.

Marx SK, McGowan HA and Kamber BS (2009) Long-range dust transport from eastern Australia: A proxy for Holocene aridity and ENSO-type climate variability. Earth and Planetary Sci-ence Letters 282: 167-177.

Mason JA, Lu H, Zhou Y et al. (2009) Dune mobility and aridity at the desert margin of northern China at a time of peak monsoon strength. Geology 37: 947-950.

Mason JA, Swinehart JB, Lu H et al. (2008) Limited change in dune mobility in response to a large decrease in wind power in semi-arid northern China since the 1970s. Geomorphology 102: 351-363.

Mauquoy D, Van Geel B, Blaauw M et al. (2004) Changes in solar activity and Holocene climatic shifts derived from 14C wiggle-match dated peat deposits. The Holocene 14: 45-52.

Muhs DR, Budahn JR, Prospero JM et al. (2007) Geochemical evidence for African dust inputs to soils of western Atlantic islands: Barbados, the Bahamas and Florida. Journal of Geo-physical Research 112: F02009. 
Murray MR (2002) Is laser particle size determination possible for carbonate-rich lake sediments? Journal of Paleolimnology 27: 173-183.

Olivarez AMR, Owen RM and Rea DK (1991) Geochemistry of eolian dust in Pacific pelagic sediments: Implications for paleoclimatic interpretations. Geochimica et Cosmochimica Acta 55: 2147-2158.

Parplies J, Lücke A, Vos H et al. (2008) Late glacial environment and climate development in northeastern China derived from geochemical and isotopic investigations of the varved sedi-ment record from Lake Sihailongwan (Jilin Province). Journal of Paleolimnology 40: 471-487.

Petherick LM, McGowan HA and Kamber BS (2009) Recon-structing transport pathways for late Quaternary dust from eastern Australia using the composition of trace elements of long traveled dusts. Geomorphology 105: 67-79.

Porter SC (2001) Chinese loess record of monsoon climate during the last glacial-interglacial cycle. Earth-Science Reviews 54: $115-128$.

Pratte S, Bao K, Shen J et al. (2018) Recent atmospheric metal deposition in peatlands of northeast China: A review. Science of the Total Environment 626: 1284-1294.

Pratte S, Garneau M and De Vleeschouwer F (2017) Late-Holo-cene atmospheric dust deposition in eastern Canada (St. Law-rence North Shore). The Holocene 27: 12-25.

Qiao S (1993) A preliminary study on Hani peat-mire in the west part of the Changbai Mountain. Scientia Geographica Sinica 13: 279-287. (in Chinese with English abstract)

Rao W, Tan H, Jiang S et al. (2011) Trace element and REE geo-chemistry of fine- and coarse-grained sands in the Ordos des-erts and links with sediments surrounding areas. Chemie der Erde 71: 155-170.

Rea DK and Leinen M (1988) Asian aridity and the zonal west-erlies: Late Pleistocene and Holocene record of eolian deposition in the northwest Pacific Ocean. Palaeogeography, Palaeoclimatology, Palaeoecology 66: 1-8.

Reimann C, Filzmoser P, Garret R et al. (2008) Statistical Data Analysis Explained: Applied Environmental Statistics with R. Chichester: John Wiley \& Sons.

Reimer PJ, Bard E, Bayliss A et al. (2013) IntCal13 and Marine13 radiocarbon age calibration curves 0-50,000 years cal BP. Radiocarbon 55: 1869-1887.

Roe G (2009) On the interpretation of Chinese loess as a paleocli-mate indicator. Quaternary Research 71: 150-161.

Sapkota A, Cheburkin AK, Bonani G et al. (2007) Six millen-nia of atmospheric dust deposition in southern South America (Isla Navarino, Chile). The Holocene 17: 561-572.

Schettler G, Liu Q, Mingram J et al. (2006a) East-Asian monsoon variability between 15000 and 2000 cal. yr BP recorded in varved sediments of Lake Sihailongwan (northeastern China, Long Gang volcanic field). The Holocene 16: 1043-1057.

Schettler G, Liu Q, Mingram J et al. (2006b) Palaeovariations in the East-Asian Monsoon regime geochemically recorded in varved sediments of Lake Sihailongwan (Northeast China, Jilin Province). Part 1: Hydrological conditions and dust flux. Journal of Paleolimnology 35: 239-270.

Schröder C, Thiele A, Wang S et al. (2007) Hani-mire: A percolation mire in northeast China. Peatlands International 2: 2124.

Schuetz L (1989) Atmospheric mineral dust-properties and source markers. In: Leinen M and Sartheim M (eds) Paleoclimatology and Paleometeorology: Modern and Past Pat-terns of Global Atmospheric Transport (NATO ASI Series C: Mathematical and Physical Sciences), vol. 282. Dordrecht: Kluwer Academic Publishers, pp. 359-384.

Schültz F and Lehmkuhl F (2009) Holocene climatic change and the nomadic Anthropocene in Eastern Tibet: Palynological and geomorphological results from the Nianbaoyeze Mountains. Quaternary Science Reviews 28: 1449-1471.

Shen J, Liu X, Wang S et al. (2005) Palaeoclimatic changes in the Qinghai Lake area during the last 18,000 years. Quaternary International 136: 131-140.

Shoenfelt EM, Winckler G, Lamy F et al. (2018) Highly bioavail-able dust-borne iron delivered to the Southern Ocean during glacial periods. Proceedings of the National Academy of Sciences of the United States of America 115: 11180-11185.

Shotyk W (1997) Atmospheric deposition and mass balance of major and trace elements in two oceanic peat profiles, northern Scotland and Shetland Islands. Chemical Geology 138: 55-72.

Shotyk W, Krachler M, Martinez-Cortizas A et al. (2002) A peat bog record of natural, pre-anthropogenic enrichments of trace elements in atmospheric aerosols since $12370 \mathrm{C}-14 \mathrm{yr} \mathrm{BP}$, and their variation with Holocene climate change. Earth and Planetary Science Letters 199: 21-37. 
Shotyk W, Weiss D, Appleby PG et al. (1998) History of atmo-spheric lead deposition since 12,370 14C yr BP from a peat bog, Jura Mountains, Switzerland. Science 281: 1635-1640.

Shotyk W, Weiss D, Kramers JD et al. (2001) Geochemistry of the peat bog at Etang de la Gruère, Jura Mountains, Switzerland, and its record of atmospheric $\mathrm{Pb}$ and lithogenic trace metals (Sc, $\mathrm{Ti}, \mathrm{Y}, \mathrm{Zr}$, and REE) since $12,370{ }_{14} \mathrm{C}$ yr $\mathrm{BP}$. Geochimica et Cosmochimica Acta 65: 2337-2360.

Sjöström JK, Bindler R, Granberg T et al. (2019) Procedure for organic matter removal from peat samples for XRD mineral analysis. Wetlands 39: 473-481.

Smith BJ, Wright JS and Whalley WB (2002) Sources of non-glacial, loess-size quartz silt and the origins of 'desert loess'. Earth-Science Reviews 59: 1-26.

Stauch G (2019) A conceptual model for the interpretation of aeo-lian sediments from a semiarid high-mountain environment since the late glacial. Quaternary Research 91: 24-34.

Stebich M, Mingram J, Han J et al. (2009) Late Pleistocene spread of (cool-)temperate forests in Northeast China and climate changes synchronous with the North Atlantic region. Global and Planetary Change 65: 56-70.

Stebich M, Rehfeld K, Schlütz F et al. (2015) Holocene vegeta-tion and climate dynamics of NE China based on the pollen record from Sihailongwan Maar Lake. Quaternary Science Reviews 124: 275-289.

Steinmann P and Shotyk W (1997) Geochemistry, mineralogy, and geochemical mass balance on major elements in two peat bog profiles (Jura Mountains, Switzerland). Chemical Geology 138: 25-53.

Sun J, Li SH, Han P et al. (2006) Holocene environmental changes in the central Inner Mongolia, based on single-aliquotquartz optical dating and multi-proxy study of dune sands. Palaeogeography, Palaeoclimatology, Palaeoecology 233: 5162.

Sun J, Zhang M and Liu T (2001) Spatial and temporal charac-teristics of dust storms in China and its surrounding regions, 1960-1999: Relations to source area and climate. Journal of Geophysical Research: Atmospheres 106: 10325-10333.

Taboada T, Cortizas AM, García C et al. (2006) Particle-size frac-tionation of titanium and zirconium during weathering and pedogenesis of granitic rocks in NW Spain. Geoderma 131:218-236.

Taylor SR and McLennan SM (1985) The Continental Crust: Its

Composition and Evolution. Oxford: Blackwell Scientific.

Tolonen K (1984) Interpretation of changes in the ash content of ombrotrophic peat layers. Bulletin of the Geological Society of Finland 56: 207-219.

Tsoar H and Pye K (1987) Dust transport and the question of des-ert loess formation. Sedimentology 34: 139-153.

Vanneste H, De Vleeschouwer F, Bertrand S et al. (2016) Ele-vated dust deposition in Tierra del Fuego (Chile) resulting from Neoglacial Darwin Cordillera glacier fluctuations. Jour-nal of Quaternary Science 31: 713-722.

Wang H, Chen J, Zhang X et al. (2014) Palaeosol development in the Chinese Loess Plateau as an indicator of the strength of the East Asian summer monsoon: Evidence for a mid-Holocene maximum. Quaternary International 334-335: $155-164$.

Wang L, Li J, Lu H et al. (2012) The East Asian winter monsoon over the last 15,000 years: Its links to high-latitudes and tropi-cal climate systems and complex correlation to the summer monsoon. Quaternary Science Reviews 32: 131-142.

Wang SM, Ji L, Xiang-Dong Y et al. (1994) The record of Younger Dryas event in lake sediments from Jalai Nur, Inner Mongo-lia. Chinese Science Bulletin 39: 831-835.

Wang W and Feng Z (2013) Holocene moisture evolution across the Mongolian Plateau and its surrounding areas: A synthesis of climatic records. Earth-Science Reviews 122: 38-57.

Wang Y, Liu X and Herzschuh U (2010) Asynchronous evolution of the Indian and East Asian Summer Monsoon indicated by Holocene moisture patterns in monsoonal central Asia. Earth-Science Reviews 103: 135-153.

Weber ET II, Owen RM, Dickens GR et al. (1998) Causes and implications of the middle rare earth element depletion in the eolian component of North Pacific sediment. Geochimica et Cosmochimica Acta 62: 1735-1744.

Wedepohl KH (1995) The composition of the continental crust. Geochimica et Cosmochimica Acta 59: 1217-1232.

Wei G, Xie L, Sun Y et al. (2012) Major and trace elements of a peat core from Yunnan, Southwest China: Implications for paleocli-matic proxies. Journal of Asian Earth Sciences 58: 64-77.

Weiss D, Shotyk W, Boyle EA et al. (2002a) Comparative study of the temporal evolution of atmospheric lead deposition in Scotland and eastern Canada using blanket peat bogs. Science of The Total Environment 292: 7-18. 
Weiss D, Shotyk W, Rieley J et al. (2002b) The geochemistry of major and selected trace elements in a forested peat bog, Kalimantan, SE Asia, and its implications for past atmo-spheric dust deposition. Geochimica et Cosmochimica Acta 66: 2307-2323.

Wen R, Xiao J, Chang Z et al. (2010) Holocene precipitation and temperature variations in the East Asian monsoonal margin from pollen data from Hulun Lake in northeastern Inner Mongolia, China. Boreas 39: 262-272.

Winkler MG and Wang PK (1993) The late-Quaternary vegetation and climate of China. In: Wright HE, Kutzbach JE, Webb T, et al. (eds) Global Climates Since the Last Glacial Maximum. Minneapolis, MN: University Minnesota Press, pp. 221-264.

Wu J, Liu Q, Wang L et al. (2016) Vegetation and climate change during the last deglaciation in the Great Khingan Mountain, Northeastern China. PLoS ONE 11: e0146261.

Xiao J, Xu Q, Nakamura T et al. (2004) Holocene vegetation variation in the Daihai Lake region of north-central China: A direct indication of the Asian monsoon climatic history. Quaternary Science Reviews 23: 1669-1679.

Xie $Y$ and Chi $Y$ (2016) Geochemical investigation of dry- and wet-deposited dust during the same dust-storm event in Harbin China: Constraint on provenance and implications for formation of aeolina loess. Journal of Asian Earth Sciences 120: 43-61.

Xie Y, Kang C, Chi Y et al. (2019) The loess deposits in northeast ChinaL the linkage of loess accumulation and geomorphicclimatic features at the easternmost edge of the Eurasian loess belt. Journal of Asian Earth Sciences 181: 103914.

Xie Y, Yuan F, Zhan T et al. (2017) Geochemistry of loess deposits in northeastern China: Constraint on provenance and implication for disappearance of the large Songliao palaeolake. Jour-nal of the Geological Society 175: 146-162.

Xu B, Wang L, Gu Z et al. (2018) Decoupling of climatic drying and Asian dust export during the Holocene. Journal of Geophysical Research: Atmospheres 123: 915-928.

Yang X, Scuderi L, Paillou P et al. (2011) Quaternary environ-mental changes in the drylands of China: A critical review. Quaternary Science Reviews 30: 3219-3233.

Yang X, Wang X, Liu Z et al. (2013) Initiation and variation of the dune fields in semi-arid China - with a special reference to the Hunshandake Sandy Land, Inner Mongolia. Quaternary Science Reviews 78: 369-380.

Zhang W, Zhao J-x, Chen J et al. (2018) Binary sources of Chi-nese loess as revealed by trace and REE element ratios. Journal of Asian Earth Sciences 166: 80-88.

Zhang XY, Arimoto R and An ZS (1997) Dust emission from Chinese desert sources linked to variations in atmospheric circulation. Journal of Geophysical Research: Atmospheres 102: 28041-28047.

Zhang XY, Gong SL, Zhao TL et al. (2003) Sources of Asian dust and role of climate change versus desertification in Asian dust emission. Geophysical Research Letters 30: 2272.

Zhao L, Satoh M and Inoue K (1997) Clay mineralogy and pedo-genesis of volcanic ash soils influenced by tropospheric eolian bust in Changbaishan, Sanjiaolongwan, and Wudalianchi, Northeast China. Soil Science and Plant Nutrition 43: 85-98.

Zhao Y, Yu Z and Chen F (2009) Spatial and temporal patterns of Holocene vegetation and climate changes in arid and semi-arid China. Quaternary International 194: 6-18.

Zheng Y, Pancost RD, Liu X et al. (2017) Atmospheric connec-tions with the North Atlantic enhanced the deglacial warming in northeast China. Geology 45: 1031-1034.

Zheng Y, Pancost RD, Naafs BDA et al. (2018) Transition from a warm and dry to a cold and wet climate in NE China across the Holocene. Earth and Planetary Science Letters 493: 36-46.

Zhou W, Zheng Y, Meyers PA et al. (2010) Postglacial climate-change record in biomarker lipid compositions of the Hani peat sequence, Northeastern China. Earth and Planetary Science Letters 294: 37-46.

Zhu J, Mingram J and Brauer A (2013) Early Holocene aeolian dust accumulation in northeast China recorded in varved sedi-ments from Lake Sihailongwan. Quaternary International 290-291, 299-312.

Zhu Z, Liu S and Di X (1989) Desertification and Rehabilitation in China. Lanzhou, China: International Center for Education and Research on Desertification Control.

Zhuo H, Lu H, Jia X et al. (2013) A preliminary study on human activities in sand fields of the northern China and its relation-ship with the climatic variations in Holocene. Quaternary Sciences 33(2): 303-313. 